\title{
MAGMA SUPPLY AND STORAGE AT KILAUEA VOLCANO, HAWAII, 1956-1983
}

\author{
DANIEL DZURISIN ${ }^{1}$, ROBERT Y. KOYANAGI ${ }^{2}$ and THOMAS T. ENGLISH ${ }^{2}$ \\ U.S. Geological Survey \\ ${ }^{1}$ David A. Johnston Cascades Volcano Observatory, 5400 MacArthur Blvd., Vancouver, \\ WA 98661 (U.S.A.) \\ ${ }^{2}$ Hawaiian Volcano Observatory, Hawaii National Park, HI 96718 (U.S.A.)
}

(Received August 27, 1983; revised and accepted December 4, 1983)

\section{ABSTRACT}

Dzurisin, D., Koyanagi, R.Y. and English, T.T., 1984. Magma supply and storage at Kilauea Volcano, Hawaii, 1956-1983. J. Volcanol. Geotherm. Res., 21: 177-206.

Shallow crustal magma reservoirs beneath the summit of Kilauea Volcano and within its rift zones are linked in such a way that the magma supply to each can be estimated from the rate of ground deformation at the volcano's summit. Our model builds on the well-documented pattern of summit inflation as magma accumulates in a shallow summit reservoir, followed by deflation as magma is discharged to the surface or into the rift zones. Magma supply to the summit reservoir is thus proportional to summit uplift, and supply to the rift zones is proportional to summit subsidence; the average proportionality constant is $0.33 \times 10^{6} \mathrm{~m}^{3} / \mu \mathrm{rad}$. This model yields minimum supply estimates because it does not account for magma which escapes detection by moving passively through the summit reservoir or directly into the rift zones.

Calculations suggest that magma was supplied to Kilauea during July 1956- April 1983 at a minimum average rate of $7.2 \times 10^{6} \mathrm{~m}^{3} / \mathrm{month}$. Roughly $35 \%$ of the net supply was extruded; the rest remains stored within the volcano's east rift zone $(55 \%)$ and southwest rift zone (10\%). Periods of relatively rapid supply were associated with the large Kapoho eruption in 1960 and the sustained Mauna Ulu eruptions in 1969-1971 and 1972-1974. Bursts of harmonic tremor from the mantle beneath Kilauea were also unusually energetic during 1968-1975, suggesting a close link between Kilauea's deep magma supply region and shallow storage reservoirs. It remains unclear whether pulses in magma supply from depth give rise to corresponding increases in shallow supply, or if instead unloading of a delicately balanced magma transport system during large eruptions or intrusions triggers more rapid ascent from a relatively constant mantle source.

INTRODUCTION

Background and purpose

A critical factor governing the behavior of an actrve basaltic shielefsolcano is the rate at which magma is supplied to the volcames edifice fromoits sougce

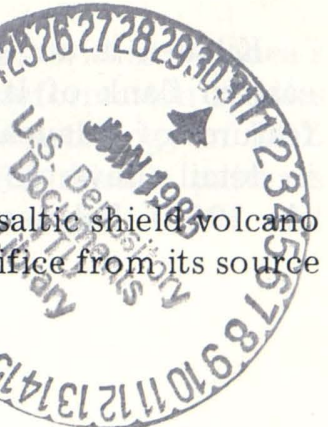


at depth. Accordingly, several attempts have been made to estimate the average rate of magma supply to Kilauea, which is among the most intensely studied volcanoes in the world.

The most direct and reliable estimates were made by Swanson (1972), who determined the rate of extrusion for 3 sustained eruptions at Kilauea during 1952-1971 to be essentially constant at $9 \times 10^{6} \mathrm{~m}^{3} /$ month. He argued from the lack of net summit deformation (suggesting minimal changes in subsurface storage) and from the character of the eruptions (steady extrusion via well-established feeding conduits) that this extrusion rate was equal to the average rate of magma supply from depth. This contention was supported by Dzurisin et al. (1980), who calculated an average supply rate of $9 \pm 3 \times 10^{6} \mathrm{~m}^{3} / \mathrm{month}$ during December 1975 -June 1976 from a model of simultaneous microgravity and vertical deformation measurements.

More recently, Duffield et al. (1982) calculated an average supply rate to Kilauea of $6 \times 10^{6} \mathrm{~m}^{3} /$ month during June 1971 -January 1972 by considering measured summit volume changes as well as observed extrusion rates. Dvorak et al. (1983) used a similar approach to calculate an average supply rate of $6 \times 10^{6} \mathrm{~m}^{3} /$ month for October 1966 -September 1970 . Both estimates are probably minimum values, because they do not include magma which may have accumulated in Kilauea's rift zones without causing measurable deformation of the summit region.

Taken together, these studies suggest that magma has been delivered to Kilauea at an average rate of $9 \pm 3 \times 10^{6} \mathrm{~m}^{3} /$ month since 1952 . Swanson (1972) used an analysis by Moore (1970) of Hawaiian tide gauge records as evidence that this rate may apply equally well throughout at least historic time, although Bargar and Jackson (1974) argued that the average rate of growth of the Hawaiian chain over geologic time has been almost an order of magnitude less. We concur with the conclusion that magma supply to Kilauea has been relatively constant for at least several decades, but are also intrigued by the possibility of detecting subtle changes in supply rate through time. Comparison of various supply estimates for this purpose is complicated by the fact that each was derived using a different technique and/or data set. Our goal here is not to supplant these detailed analyses for specific intervals, but rather to develop a simplified method of estimating magma supply to Kilauea that can be applied uniformly to a relatively long interval, in an attempt to assess the constancy of magma supply through time.

\section{Setting and earlier work}

Kilauea is an active basaltic shield volcano nestled against the southeastern flank of larger Mauna Loa on the island of Hawaii (Fig. 1). Salient features of Kilauea's subsurface structure and dynamics have been described in detail elsewhere (e.g., Eaton and Murata, 1960; Eaton, 1962; Duffield et al., 1982). Kilauea eruptions generally occur within its summit caldera or 


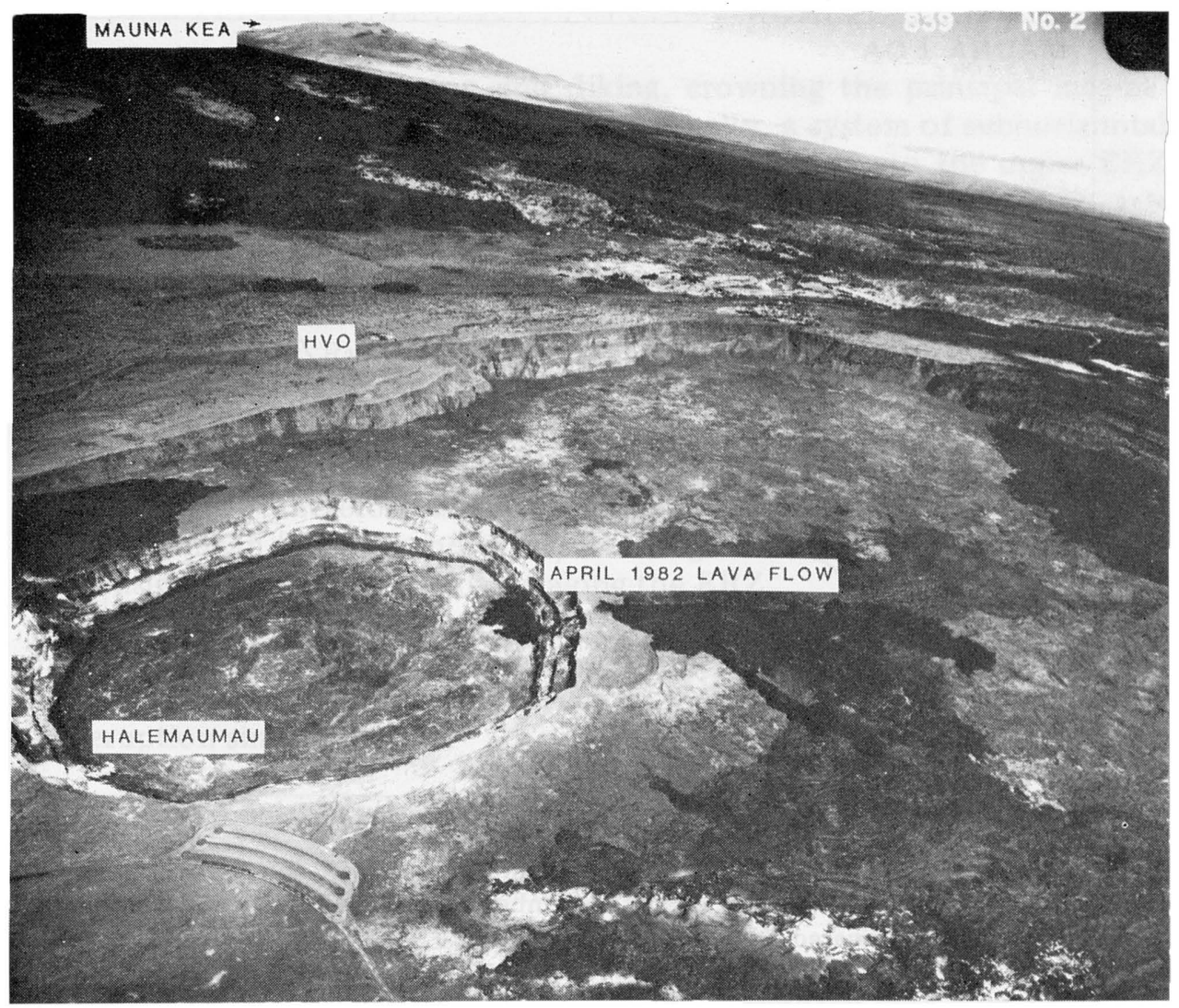

Fig. 1. Oblique aerial view of the Kilauea summit region, showing Halemaumau (lower left) nested within Kilauea caldera. Mauna Kea appears in the upper left, partially obscured by the east flank of Mauna Loa. Direction of view is northeast.

along prominent rift zones radiating eastward and southwestward from the summit (Fig. 2). Seismic and ground-deformation studies indicate that eruptions are fed from a magma-storage reservoir centered $2-6 \mathrm{~km}$ beneath the caldera (Koyanagi et al., 1974), which in turn is supplied with magma from a zone of partial melting in the upper mantle (Eaton, 1962). Prior to some rift eruptions, a pattern of migrating seismicity and ground deformation suggests lateral transport of magma from the summit storage reservoir to the eventual eruption site via shallow rift-zone conduits. In other cases, a gap in seismicity between the summit and eruption site implies the presence of a "fluid core" in the upper east rift zone.

The existence of subsidiary magma storage reservoirs within Kilauea's east rift zone (ERZ) has been inferred from ground-deformation studies (Jackson et al., 1975; Swanson et al., 1976b), from the petrology of ERZ lavas (Wright and Fiske, 1971; Moore, 1983), from ERZ seismic patterns (Koyanagi et al., 1981), from geoelectric studies (Keller et al., 1977), and 


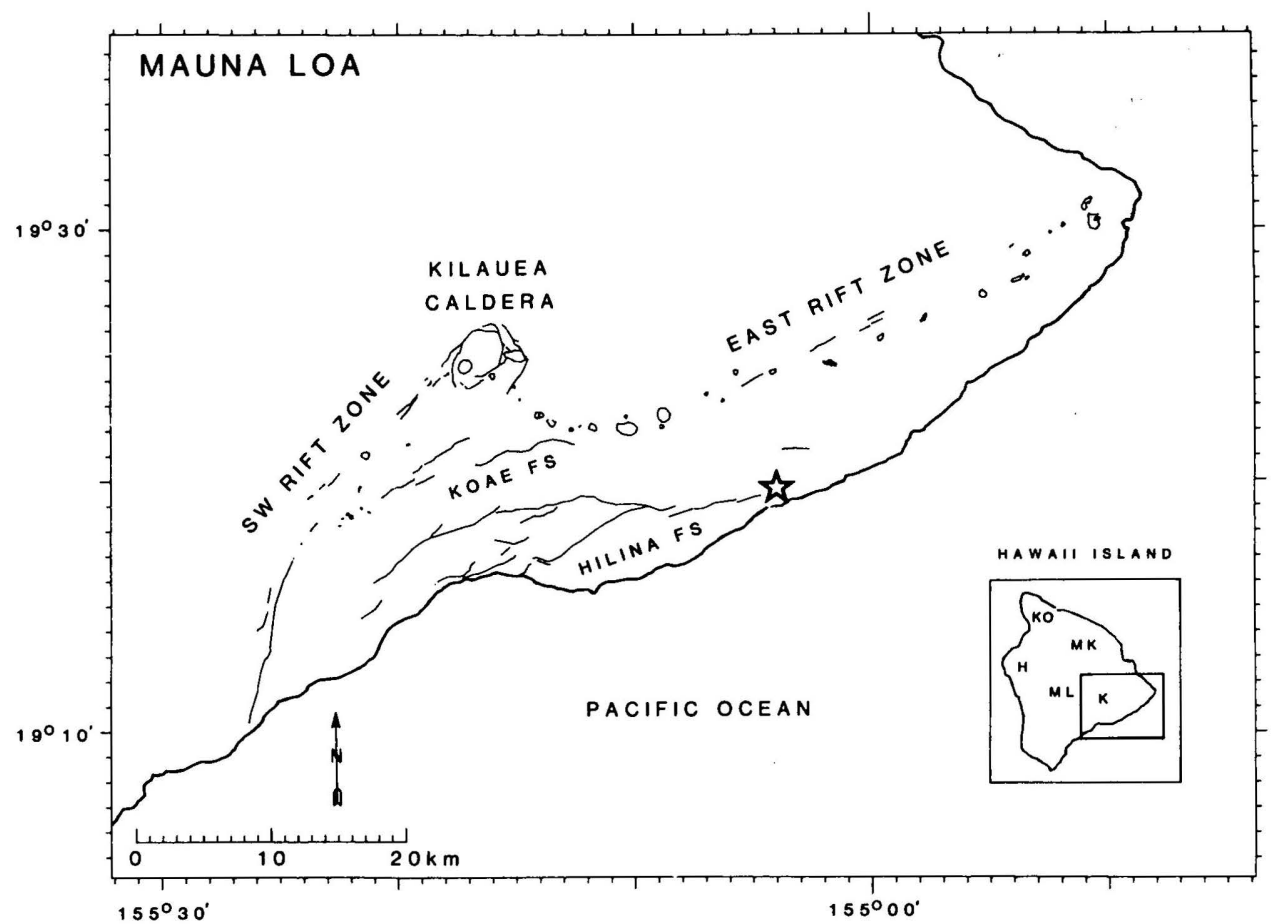

Fig. 2. Map of Kilauea Volcano, showing its summit caldera, rift zones, and prominent fault systems (FS). The epicenter of the 29 November 1975 earthquake beneath Kilauea's southeastern flank is indicated by a star.

from the dynamics of recent eruptions and intrusions (Dzurisin et al., 1980). Both Eaton (1962) and Swanson et al. (1976b) suggested that the upper ERZ is underlain by a magmatic core hydraulically linked to the summit reservoir. Duffield et al. (1982) argued that, in contrast to the ERZ, eruptions from Kilauea's southwest rift zone (SWRZ) are fed directly from active lava lakes in Kilauea caldera or from shallow cupolas at the top of the summit magma reservoir, implying substantially less rift-zone storage than is inferred for the ERZ.

These earlier models of Kilauea's subsurface structure and dynamics were synthesized and extended by Ryan et al. (1981), who defined four principal systems for magma transport and storage within the volcano. A primary conduit consisting of a vertical pipe of intense fracturing and inferred intrusion rises from a deep source region to within $6.5 \mathrm{~km}$ of the summit caldera. The lower part of the summit magma reservoir encompasses the top of this conduit and extends to within $6 \mathrm{~km}$ of the surface. It is an aseismic zone interpreted to contain relatively high fluid-to-rock ratios and passageways for further vertical transport within the summit reservoir, and for lateral leakage into the ERZ. The upper portion of the reservoir from 2 to $1 \mathrm{~km}$ depth is characterized by intense seismicity; it is interpreted as a 
region of pervasive fracturing and diking, crowning the principal magmastorage zone between 6 and $2 \mathrm{~km}$ depth. Finally, a system of subhorizontal passageways connects the base of the summit reservoir to the upper ERZ and its network of subsidiary magma-storage reservoirs.

Ryan et al. (1981) show no comparable feature connecting the summit reservoir to the SWRZ, consistent with the distinction between the two rift zones drawn by Duffield et al. (1982). We accept a difference in degree, but point out that Ryan et al. (1981) concentrated on summit and ERZ structure by analyzing seismic data from 1971-1973 only; their result for the SWRZ is poorly constrained. Several SWRZ intrusions and 2 SWRZ eruptions since 1956 imply that the SWRZ stores magma at least sporadically, and we have therefore included a small SWRZ reservoir in our model. We do not mean to imply, however, that magma storage within the SWRZ is as extensive or persistent as storage along the ERZ.

To illustrate the close connection between Kilauea's summit and riftzone reservoirs which forms the basis for our model, we begin with a brief chronology of historic activity at Kilauea, including pertinent references for each eruption since 1823.

\section{CHRONOLOGY}

\section{3-1923: Nearly continuous summit lava lake}

The written record of eruptive activity at Kilauea began with the journal of William Ellis (1963), reprinted), an early missionary who first described Kilauea caldera and its active lava lake during August 1823. Except between 1894 and 1907, summit lava lakes were present almost continuously at Kilauea during the volcano's first century of recorded history, accompanied by brief outbreaks near the caldera rim in 1832, 1868, and 1877 (Macdonald and Abbott, 1970, pp. 69-77).

Relatively small eruptions occurred from Kilauea's SWRZ in 1823 and 1868; a sustained eruption there built a small lava shield, Mauna Iki, during 1919-1920. The second largest eruption in Kilauea's recorded history occurred from the volcano's lower ERZ during May-June 1840, destroying the coastal village of Nanawale (Macdonald and Abbott, 1970, pp. 71-76).

During the latter part of the nineteenth century, summit lava lake activity gradually became confined to Halemaumau, a central collapse pit which alternately filled and drained to depths of a few hundred meters. Rapid draining of lava from Halemaumau accompanied an inferred submarine eruption from Kilauea's ERZ in 1884 and led Macdonald and Abbott $(1970$, p. 77$)$ to speculate that another may have occurred there in 1886. Similar collapses of the Halemaumau lava lake preceded small eruptions from the ERZ in May 1922 and August 1923. 
The next three decades at Kilauea began with the volcano's most recent explosive eruption and saw the demise of the century-old summit lava lake. An intense swarm of earthquakes migrated down Kilauea's ERZ during April-May 1924, accompanied by dramatic subsidence of the Halemaumau lava lake and by formation of a graben that subsided more than $4 \mathrm{~m}$ along the lower ERZ. Steam explosions at Halemaumau, presumably caused by interaction of ground water with the lowered magma column, began on May 11 and reached their peak a week later (Jaggar and Finch, 1924). Rapid withdrawal of magma beneath Halemaumau removed support and caused the crater walls to collapse, thereby enlarging the diameter of the rim from roughly 400 to $900 \mathrm{~m}$; the resulting talus-floored pit was approximately $400 \mathrm{~m}$ deep by the end of the eruption. Lava returned to Halemaumau in July 1924 with the first of seven short eruptions that together reduced the depth of the crater from 400 to 230 m (Macdonald and Abbott, 1970, p. 75).

The longest repose during Kilauea's recorded history spanned the 18year interval from October 1934 to June 1952. Prolonged summit inflation followed by relatively rapid deflation suggested that magma was intruded into the volcano's rift zones at least in December 1944 and December 1950 (smaller intrusions may have gone unnoticed), but there were no eruptions. A period of increased seismic activity beneath Kilauea's summit region began with a magnitude 6.5 earthquake in April 1951 and culminated with the brief return of a lava lake to Halemaumau in June 1952 (Macdonald and Abbott, 1970, pp. 81-83). By the end of the eruption in November, Halemaumau had filled by $120 \mathrm{~m}$ and its floor had risen to within $110 \mathrm{~m}$ of the crater rim. Halemaumau erupted again briefly in May 1954, but inflation of the summit region resumed almost immediately.

\section{5-1974: Frequent ERZ eruptions}

Seismicity along Kilauea's middle ERZ gradually intensified during November 1954-February 1955, culminating in a three-month eruption which spanned more than $15 \mathrm{~km}$ of the middle and lower ERZ (Macdonald, 1959; Macdonald and Eaton, 1964). The 1955 eruption was noteworthy because it ended the 115 year repose of the ERZ since the large 1840 eruption, and marked the beginning of a period of frequent ERZ activity which included the largest eruptions in Kilauea's recorded history, the 1969-1971 and 1972-1974 eruptions of Mauna Ulu.

The interval 1955-1960 also marked the beginning of modern seismic and ground-deformation studies at Kilauea. A 3-m base water-tube tiltmeter was installed in Uwekahuna vault near the northwest rim of Kilauea caldera (Fig. 3) in July 1956; since then it has provided a continuous daily record of summit tilt at Kilauea. Starting at about the same time, the Kilauea 


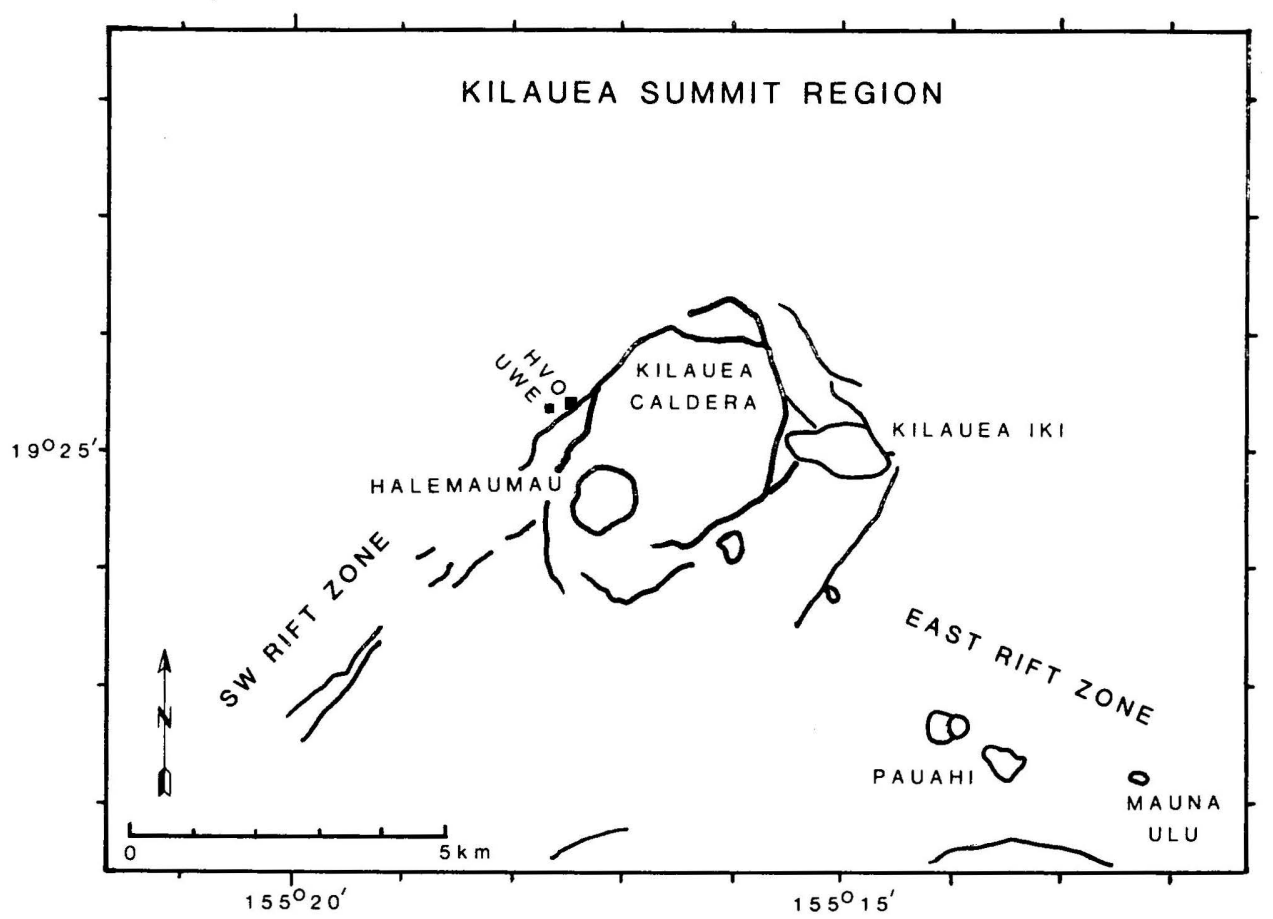

Fig. 3. Detailed map of the summit region of Kilauea Volcano, showing the Hawaiian Volcano Observatory (HVO) and Uwekahuna vault (UWE) along the northwest rim of Kilauea caldera.

seismic network was gradually upgraded with high gain electromagnetic seismometers in the summit region and eventually along both rift zones. The instrumental record of Kilauea activity is therefore relatively complete since 1956, providing a uniform data base from which to estimate magma supply for the ensuing 27-year interval.

The modern monitoring era at Kilauea began in dramatic fashion with a spectacular eruption in Kilauea Iki pit crater on the east rim of Kilauea caldera during November-December 1959 (Richter et al., 1970; Table I). Roughly $40 \times 10^{6} \mathrm{~m}^{3}$ of basalt were extruded during 17 eruptive phases, some of which included lava fountains more than $500 \mathrm{~m}$ high. Soon after the final extrusive phase on 20 December 1959, seismicity along the lower ERZ increased markedly near the village of Kapoho, $35 \mathrm{~km}$ east (downrift) of Kilauea Iki. During the ensuing eruption in January-February 1960, roughly $120 \times 10^{6} \mathrm{~m}^{3}$ of basalt were extruded as lava flows which eventually engulfed most of Kapoho village and extended the east coastline of Hawaii by nearly a kilometer (Macdonald and Abbott, 1970, pp. 92-97).

Lava returned briefly to Halemaumau in February, March, and July 1961 (Richter et al., 1964). These small summit outbreaks were followed by an intrusion into the upper SWRZ (May 1963), by at least 2 intrusions into the ERZ (July 1963 and August 1965), and by 9 small eruptions from the 
TABLE I

Kilauea eruptions and intrusions 1959-1983

\begin{tabular}{|c|c|c|c|c|c|}
\hline \multirow[t]{2}{*}{ Date } & \multirow[t]{2}{*}{$\begin{array}{l}\text { Duration } \\
\text { (days) }\end{array}$} & \multicolumn{3}{|c|}{$\begin{array}{l}\text { Location and } \\
\text { type of event* }\end{array}$} & \multirow[t]{2}{*}{$\begin{array}{l}\text { Erupted volume } \\
\left(10^{6} \mathrm{~m}^{3}\right)\end{array}$} \\
\hline & & $\mathrm{S}$ & ERZ & SWRZ & \\
\hline $11 / 14 / 59$ & 36 & $\mathrm{E}$ & - & - & 40 \\
\hline $1 / 13 / 60$ & 36 & - & $\mathrm{E}$ & - & 119 \\
\hline $2 / 24 / 61$ & 1 & $E$ & - & - & 0.2 \\
\hline $3 / 3 / 61$ & 22 & $\mathrm{E}$ & - & - & 0.3 \\
\hline $7 / 10 / 61$ & 7 & $\mathrm{E}$ & - & - & 13 \\
\hline $9 / 22 / 61$ & 4 & - & $E$ & - & 2.5 \\
\hline $12 / 7 / 62$ & 3 & - & $\mathrm{E}$ & - & 0.3 \\
\hline $5 / 9 / 63$ & 1 & - & $\cdots$ & I & - \\
\hline $7 / 1 / 63$ & 2 & - & I & - & - \\
\hline $8 / 21 / 63$ & 3 & - & $\mathrm{E}$ & - & 0.8 \\
\hline $10 / 5 / 63$ & 2 & - & $\mathrm{E}$ & - & 8 \\
\hline $3 / 5 / 65$ & 11 & - & $\mathrm{E}$ & - & 18 \\
\hline $8 / 25 / 65$ & 1 & - & I & - & - \\
\hline $12 / 24 / 65$ & 2 & - & $\mathrm{E}$ & - & 0.8 \\
\hline $11 / 5 / 67$ & 251 & $\mathrm{E}$ & - & - & 84 \\
\hline $8 / 22 / 68$ & 5 & - & $\mathrm{E}$ & - & 0.01 \\
\hline $10 / 7 / 68$ & 16 & - & $\mathrm{E}$ & - & 7 \\
\hline $2 / 22 / 69$ & 7 & - & $E$ & - & 17 \\
\hline $5 / 24 / 69$ & 875 & - & $\mathrm{EP}$ & - & 185 \\
\hline $11 / 3 / 69$ & 1 & - & I & - & - \\
\hline $1 / 22 / 70$ & 1 & I & - & - & - \\
\hline $5 / 15 / 70$ & 2 & - & I & - & - \\
\hline $6 / 11 / 71$ & 3 & - & - & I & - \\
\hline $8 / 14 / 71$ & 1 & $E$ & - & - & 10 \\
\hline $9 / 24 / 71$ & 5 & - & - & $\mathrm{E}$ & 8 \\
\hline $12 / 24 / 71$ & 6 & - & - & $\mathrm{I}$ & - \\
\hline $2 / 4 / 72$ & 455 & - & $\mathrm{EP}$ & - & 125 \\
\hline $5 / 5 / 73$ & 1 & - & $\mathrm{E}$ & - & 1 \\
\hline $5 / 7 / 73$ & 187 & - & EP & - & 2.5 \\
\hline $6 / 9 / 73$ & 1 & - & I & - & - \\
\hline $11 / 10 / 73$ & 30 & - & $\mathrm{E}$ & - & 3 \\
\hline $12 / 12 / 73$ & 222 & - & EP & $\div$ & 30 \\
\hline $3 / 24 / 74$ & 1 & - & I & - & - \\
\hline $7 / 19 / 74$ & 3 & $\mathrm{E}$ & - & - & 10 \\
\hline $9 / 19 / 74$ & 1 & $\mathbf{E}$ & - & - & 11 \\
\hline $12 / 31 / 74$ & 1 & - & - & $\mathrm{E}$ & 15 \\
\hline $11 / 29 / 75$ & 1 & $\mathrm{E}$ & - & - & 0.2 \\
\hline $6 / 21 / 76$ & 1 & - & I & - & - \\
\hline $7 / 14 / 76$ & 1 & - & I & - & - \\
\hline $2 / 8 / 77$ & 1 & - & I & - & - \\
\hline $9 / 12 / 77$ & 20 & - & $\mathrm{E}$ & - & 40 \\
\hline $5 / 29 / 79$ & 1 & - & I & - & - \\
\hline $8 / 12 / 79$ & 1 & - & I & - & - \\
\hline $\begin{array}{r}11 / 16 / 79 \\
3 / 2 / 80\end{array}$ & 1 & - & $\begin{array}{l}\mathrm{E} \\
\mathrm{I}\end{array}$ & - & $\begin{array}{r}0.4 \\
-\quad 1\end{array}$ \\
\hline
\end{tabular}


TABLE I (continued)

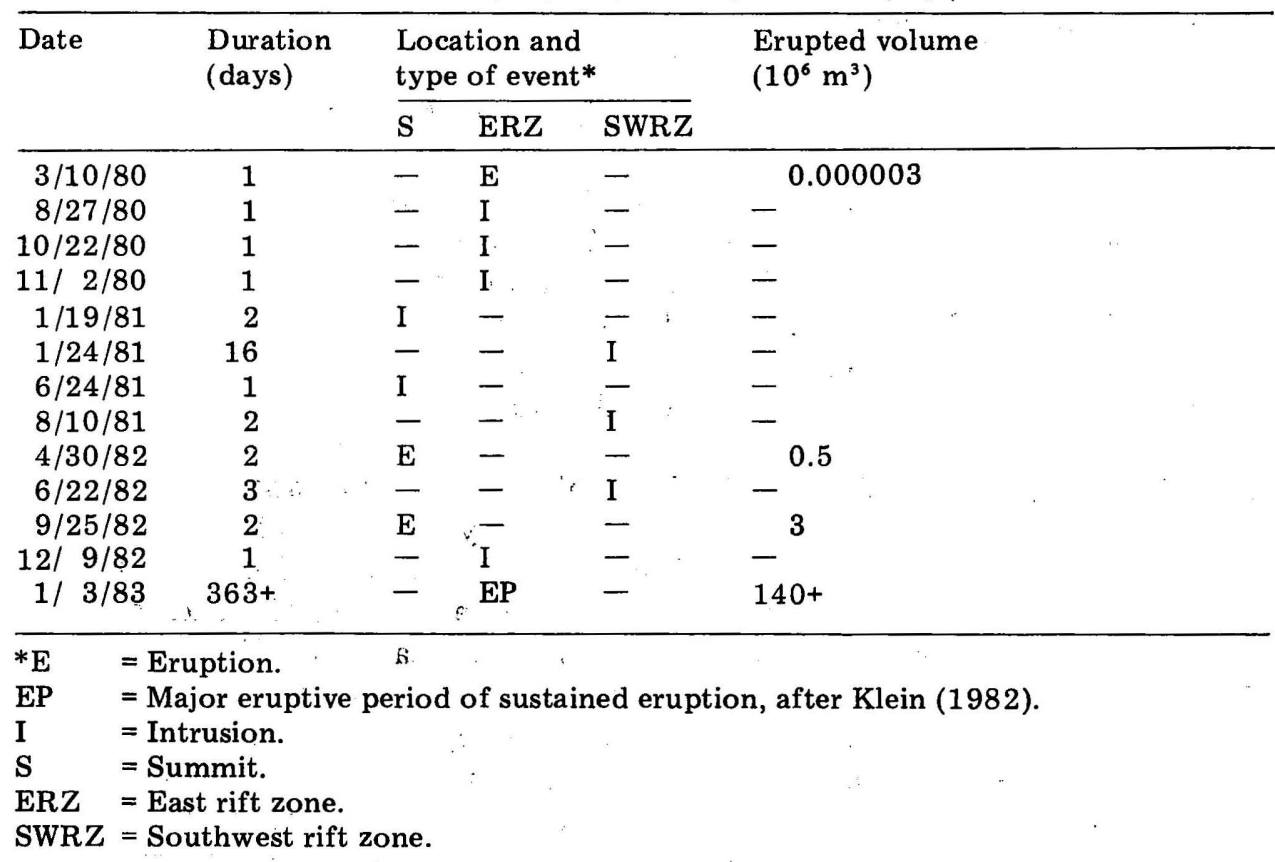

ERZ during September 1961-February 1969 (Moore and Krivoy, 1964; Wright et al., 1968; Jackson et al., 1975; Swanson et al., 1976b). This period of predominantly ERZ activity was interrupted by a sustained lava lake in Halemaumau during November 1967-July 1968. The lake surface rose to within $30 \mathrm{~m}$ of the crater rim during the height of the eruption, before partially subsiding owing to drainback (Kinoshita et al., 1969; Macdonald and Abbott, 1970, pp. 99-100).

The longest, largest, and most varied eruptions in Kilauea's recorded history began along the volcano's upper ERZ on 24 May 1969 (Swanson et al., 1979). Continuous activity until October 1971 and again between February 1972 and July 1974 was witnessed from close quarters by scores of volcanologists and thousands of visitors to Hawaii National Park. Slow effusion punctuated by spectacular lava fountains up to $540 \mathrm{~m}$ high eventually built Mauna Ulu ("Growing Mountain") lava shield to a height of 90 $\mathrm{m}$, pushed lava flows to the island's southeast shore, filled two pit craters and partly filled a third, and contributed substantially to our understanding of eruptive products and processes at basaltic shield volcanoes.

Small eruptions occurred elsewhere along the ERZ in May 1973 (Pauahi and Hiiaka pit craters), and during November-December 1973 (Pauahi). Brief outbreaks also occurred in the Kilauea summit region in August 1971 (Duffield et al., 1982), July 1974, and September 1974. The first eruption from Kilauea's SWRZ since 1920 migrated $12 \mathrm{~km}$ downrift from the summit caldera during September 1971 (Duffield et al., 1982); a small SWRZ erup- 
tion and inferred large intrusion occurred during December 1974-January 1975 (Koyanagi et al., 1978a, b).

\section{5-1981: Large Kilauea earthquake followed by frequent intrusions}

1975 was a very dynamic year for Hawaiian volcanoes. The longest repose in Mauna Loa's recorded history ( $25 \mathrm{yr}$ ) was broken in July 1975 by a brief summit eruption and an intrusion into that volcano's northeast rift zone (Lockwood et al., 1976). In November 1975, a magnitude 7.2 earthquake beneath Kilauea's south flank interrupted 2 decades of frequent ERZ eruptions and significantly altered the volcano's behavior for several years.

The Kalapana earthquake on 29 November 1975, the largest to strike Hawaii in more than a century, was anticipated by Swanson et al. (1976a), who correctly surmised that repeated intrusions into the ERZ since 1955 had made the south flank susceptible to gravitational failure. The earthquake triggered a small-volume eruption within Kilauea caldera (Tilling et al., 1976), but the volume of magma erupted was only a small fraction of that which drained from summit storage, as evidenced by the second-largest summit deflation at Kilauea since 1956 (205 $\mu \mathrm{rad}$ at Uwekahuna). Although masked in large part by an intense aftershock sequence, earthquakes along the ERZ probably recorded the intrusion of magma which had previously resided in summit storage.

Later analysis of the regional deformation network at Kilauea revealed that the entire volcanic edifice moved differentially southeastward during the earthquake. Ground displacements were most pronounced along Hawaii's southeastern coast, where movements as large as $3 \mathrm{~m}$ downward and $8 \mathrm{~m}$ southeastward were recorded (Lipman et al., 1984). Vertical and horizontal movements generally decreased northward but extended across Kilauea's ERZ and onto the south flank of neighboring Mauna Loa. The upper ERZ extended by $70 \mathrm{~cm}$ during or immediately after the earthquake, and by an additional $93 \mathrm{~cm}$ during January 1976-May 1982 (HVO, unpublished data).

In addition to its immediate effects on Kilauea, the November 1975 earthquake substantially altered the volcano's patterns of seismic strain release and surface deformation for several years. Prior to the 1975 earthquake, most Kilauea earthquakes occurred beneath the summit region or along the rift zones, presumably in direct response to magma movements into those areas. In addition to continuing seismicity in these traditionally active areas, the south flank of Kilauea has been notably more active since 1975 . South-flank seismicity has been more intense and prolonged than would be expected from a typical aftershock sequence, suggesting a longer-term change in the volcano's response to stress. Such change most likely reflects continuing south-flank mobility in response to gravitational and magmarelated stresses caused by intrusions into the ERZ.

This interpretation is consistent with a distinct change in the pattern of 
surface deformation at Kilauea during 1976-1977: Prior to the earthquake; horizontal and vertical deformation patterns in the summit region: were typically symmetric, as the surface flexed in response to inflation or deflation of the summit magma reservoir. For more than a year following the earthquake, however, typical inflation/deflation cycles at Kilauea were largely masked by continuing seaward movement of the volcano's south flank (Lipman et al., 1984):

Finally, these seismic and deformation changes were symptomatic of a significant change in the pattern of magma movements within Kilauea. The interval November 1975-September 1977, which ended with an eruption along Kilauea's middle ERZ (Moore et al., 1980), included at least three distinct ERZ intrusions that did not culminate in eruptions (Dzurisin et al., 1980). Although similar intrusions had occurred before 1975, the ratio of intrusions to eruptions increased from roughly $1: 2$ during 19601975 to $4: 1$ during $1976-1980$. If we consider only the 20 events bracketing the November 1975 earthquake, the intrusion/eruption ratio switched from $1: 4$ before the earthquake to $4: 1$ in favor of intrusions afterward (Table I).

The predominance of intrusions over eruptions continued at Kilauea from September 1977 through 1981, as evidenced by 7 intrusions into the ERZ during 1979-1980, 2 into the summit region and 2 into the SWRZ during 1981 (including the largest intrusion in Kilauea's geophysically recorded history during August 1981), but only 1 small ERZ eruption in November 1979. An intrusion beneath Mauna Ulu on the upper ERZ in March 1980 may have fed the smallest eruption in Hawaiian history, as evidenced by roughly $3 \mathrm{~m}^{3}$ of fresh spatter discovered in March 1982 (HVO, unpublished data). Even smaller was the renowned eruption of about $1 \mathrm{~m}^{3}$ (dense rock equivalent) of basaltic pumice from a deep drill hole at Krafla volcano, Iceland in September 1977 (Björnsson and Sigurdsson, 1978; Larsen et al., 1978).

The first signs that Kilauea had begun to recover from the effects of the November 1975 earthquake came almost 7 years later, in the form of 2 brief summit eruptions during April-May and September 1982. A sustained eruption from the volcano's middle ERZ beginning in January 1983 (and continuing as of December 1983) provided further evidence that Kilauea's recovery was nearly complete. Repeated intrusions into the ERZ and SWRZ may finally have overcome the large dilation caused by the Kalapana earthquake, thereby heralding a return to the pattern of frequent Kilauea eruptions established during $1823-1974$.

\section{AN EMPIRICAL MODEL FOR KILAUEA MAGMA SUPPLY}

\section{Connection between summit and rift zone reservoirs}

Our model, which is based on the relation between shallow magma reservoirs beneath Kilauea's summit region and along its rift zones, was particular- 
ly well illustrated by the volcano's behavior during April-August 1980 . After a small eruption near Pauahi crater along the upper ERZ in November 1979 , the summit region rapidly re-inflated to its pre-eruption level, but then deformed very little until successive intrusions into the ERZ on March 2 and March 10, 1980 (Dzurisin and Koyanagi, 1981).

Beginning in mid-April 1980, the Kilauea summit region underwent a series of periodic tilt oscillations which suggested a particularly close connection between magma reservoirs beneath the summit and along the upper ERZ. Five sequential inflation/deflation cycles occurred by the end of June, with a periodicity of roughly 14 days per cycle. These initial oscillations were in phase with the fortnightly earth tide at Kilauea, but this pattern was not maintained during subsequent tilt excursions in July and August ( $F$. Klein, pers. commun., 1980).

The summit region slowly inflated at the beginning of each episode, accompanied by increased summit seismicity (Fig. 4). As the capacity of the summit reservoir became taxed with increasing storage, shallow summit

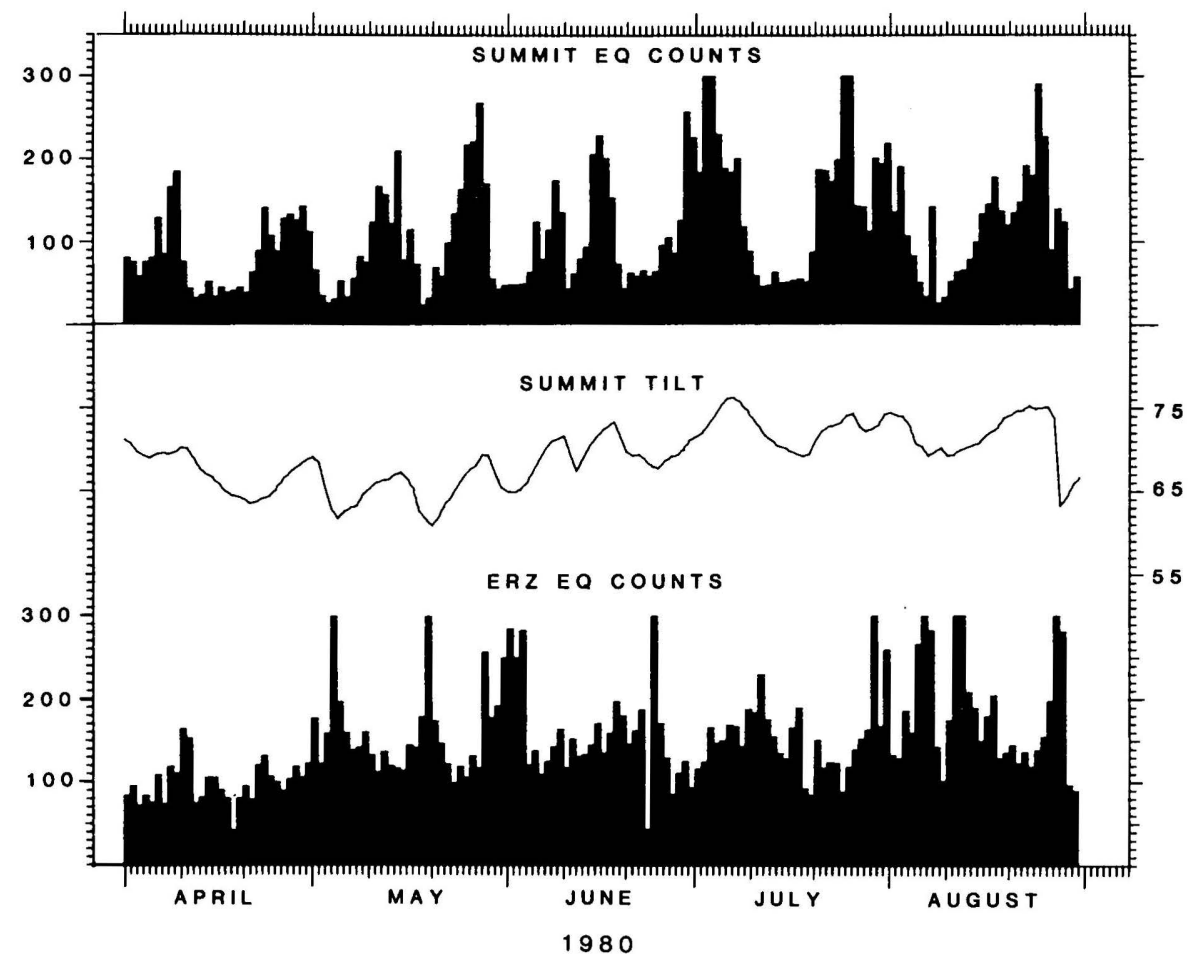

Fig. 4. Summit tilt (arbitraty microradian scale), summit earthquake counts, and ERZ earthquake counts during April-August 1980. During this unusual interval, episodes of steady summit inflation as recorded by a mercury-capacitance tiltmeter in Uwekahuna vault were accompanied by corresponding increases in summit earthquakes. With the onset of gradual summit deflation, summit quakes decreased and ERZ quakes increased markedly as magma was transferred gradually from the summit reservoir to the rift zone. 
earthquakes increased dramatically. When the summit chamber eventually began leaking, summit seismicity declined and slow deflation was quickly followed by increased seismicity along the ERZ. The suspicion that magma moved from summit storage into the ERZ during these slow summit deflations was confirmed by tilt surveys, which defined a broad zone of uplift centered near Kalalua (Fig. 5). The oscillatory pattern was eventually broken by another rapid intrusion into the ERZ in August 1980.

Similar tilt oscillations occurred during the Mauna Ulu eruptions in 1969-1971 (Swanson et al., 1979) and 1972-1974, and during the sustained ERZ eruption which began in January 1983. We suggest that the close connection between Kilauea's summit and ERZ magma reservoirs implied by these episodes provides a basis of an empirical model of magma supply and storage at Kilauea. Following a brief discussion of the model and its limitations, we investigate its implications for magma supply to Kilauea during 1956-1983.

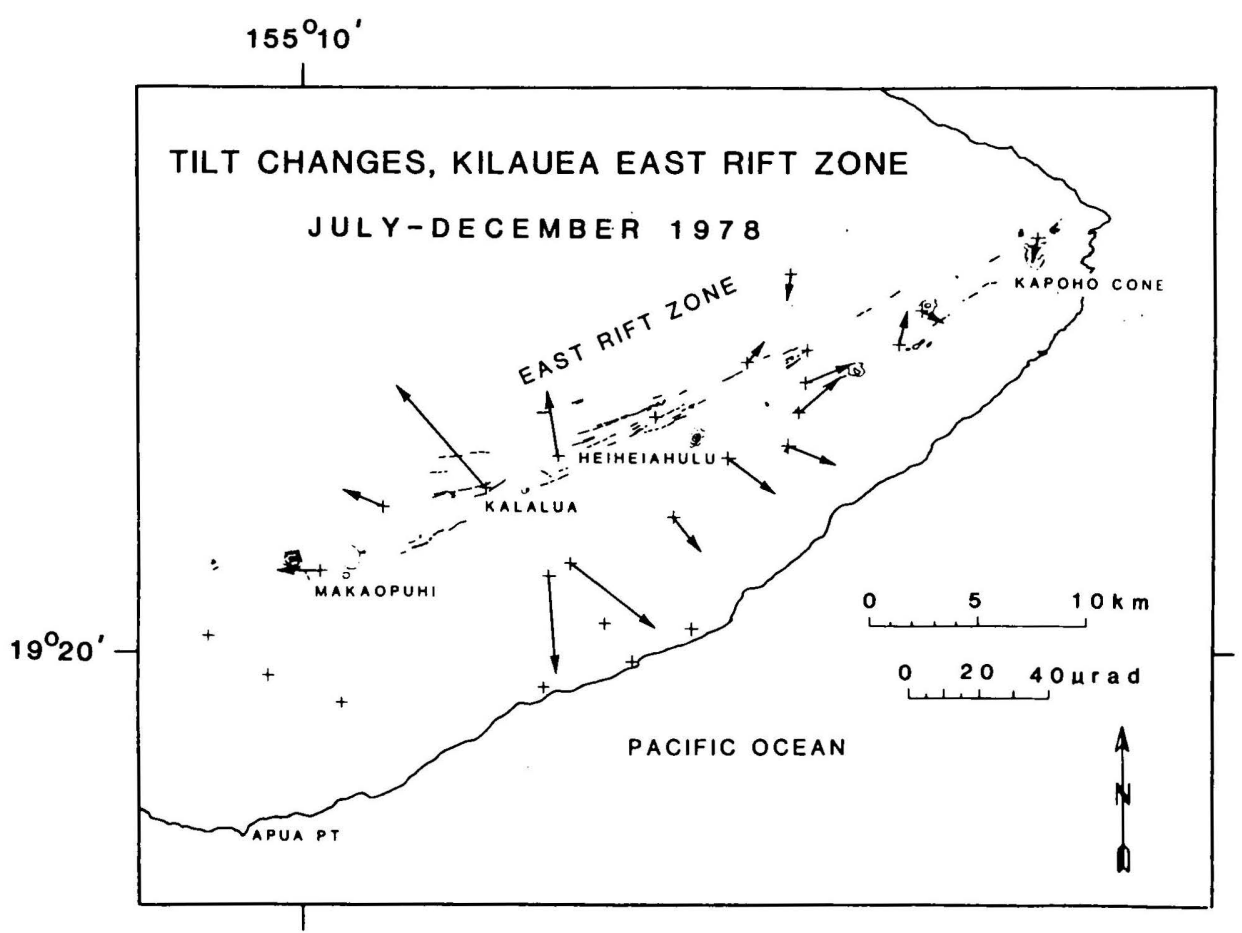

Fig. 5. Results of tilt surveys showing inflation along Kilauea's ERZ during July-December 1978; measurements after a series of summit tilt oscillations during April-August 1980 showed a similar pattern, but were less complete. Inflation of the rift zone reflects relatively passive, steady magma transfer from the summit reservoir to the rift zone following the 1975 Kalapana earthquake. Arrows are vectors showing direction and magnitude of tilt, in microradians. Crosses, tilt stations. 


\section{Theoretical considerations}

We assume that Kilauea's mantle source, summit magma reservoir, and two rift zones form a closed system for magma supply, transfer, and storage within the volcano. In other words, the volume of magma supplied from a deep melting source is balanced by surface extrusion, storage changes within the summit reservoir, and storage changes along the volcano's rift zones. We can calculate the magma supply rate to Kilauea as a function of time if we can specify the volcano's mean extrusion rate and the rates of change in summit and rift-zone storage, each as a function of time.

This information can be derived from the measured rate of surface deformation at Kilauea's summit, subject to the following assumptions:

(1) the summit reservoir is primary in the sense that all magma delivered to any part of the volcano initially accumulates in the summit reservoir;

(2) any increase in summit storage is uniquely reflected by uplift of the summit region;

(3) any decrease in summit storage as evidenced by summit subsidence is accompanied by a corresponding increase in secondary storage within the rift zones, or by surface extrusion;

(4) the relation between summit storage volume and measured surface deformation is linear and constant; and

(5) the same dynamic processes occur during inflation and deflation, and hence the same relations hold.

Extruded volume as a function of time does not enter explicitly into this scheme, but is included by way of eruption-related summit deformation. We emphasize that this approach yields a minimum estimate of magma supply, because some magma might escape detection by moving passively through the summit reservoir or directly into the rift zones. This was seemingly the case during early 1967 and 1968-1969, when filling of a reservoir near Makaopuhi pit crater along the upper ERZ caused measurable uplift during a period of summit inflation (HVO, unpublished data). We also point out that our second assumption was probably violated immediately after the 1975 Kalapana earthquake, while magma refilled the summit reservoir without appreciably deforming the surface. This process caused a relative increase in local gravity in excess of that which could plausibly be attributed to measured ground deformation (Dzurisin et al., 1980).

The major advantage of this approach lies in its ability to estimate storage changes within Kilauea's rift zones solely from deformation changes measured in the summit region. Kilauea's summit is easily accessible and therefore intensively and continuously monitored, but less geodetic control exists along the volcano's largely inaccessible ERZ. Our approach is to quantify the volume of magma lost from the summit reservoir and assume that this is a reliable measure of magma delivered to the rift zones.

Summit tilt as measured by the Uwekahuna water-tube tiltmeter is the best available input to our model, because there exists a continuous long- 
term record of frequent and relatively precise measurements (daily since July 1956, with a precision of about $1 \mu \mathrm{rad}$ ). More detailed geodetic information spanning a larger area (e.g., leveling or trilateration data) is preferable for specific supply estimates during shorter intervals, but they do not provide the temporally continuous, spatially consistent data set that our model requires:'

We estimate changes in summit and rift-zone magma storage from the Uwekahuna tilt record by assuming that net summit inflation reflects increased summit storage, and cumulative summit deflation records increased rift zone storage. Net summit deflation during any interval $\Delta t=t_{2}-t_{1}$ is simply the algebraic difference between summit tilt values bracketing the interval. That is: $\Delta \tau_{\text {net }}=\tau_{2}-\tau_{1}$, where $\tau$ is any representative measure of summit tilt (in this case, the Uwekahuna water tube). Cumulative summit deflation is defined here as the sum of all deflations during $\Delta t$ which exceed instrumental uncertainty. For the Uwekahuna water-tube tilt record, we adopt $2 \mu \mathrm{rad}$ as a conservative threshold; calculations show that small changes in threshold do not significantly alter the results.

In order to convert a measure of summit deformation into an estimate of magma supply, we need to specify an empirical relationship between summit tilt change at Uwekahuna and a corresponding volume change in the summit magma reservoir. This problem has been addressed by Eaton (1962), who modeled tilt changes during the 1959-1960 Kilauea Iki/ Kapoho eruptions using a formalism developed by Mogi (1958). The following treatment parallels that of Eaton (1962), as corrected by Jackson et al. (1975, p. 15), and is based on the semi-infinite elastic model of Mogi (1958).

If we assume that ground tilting reflects volume changes in a spherical chamber of radius $a$ centered at depth $f$, the ground tilt at a point separated by distance $d$ from the deformation center is given by:

$\tau=3.5 \frac{d / f}{\left(1+d^{2} / f^{2}\right)^{5 / 2}} \tau_{\text {max }}$

where $\tau_{\max }=$ maximum tilt at $d=f / 2$.

According to this model, the volume swept out by the surface during a tilt event characterized by maximum tilt $\tau_{\max }$ is given by:

$\Delta V=2.32 \pi f^{3} \tau_{\max }$

Combining eqs. 1 and 2 , we obtain:

$\Delta V=0.66 \frac{\pi f^{4}}{d}\left(1+d^{2} / f^{2}\right)^{5 / 2} \tau$

We adopt for our purposes $f=2-4 \mathrm{~km}$, which is representative of results obtained by inversion of Kilauea leveling data (Swanson et al., 1976b) and consistent with the recent model of Ryan et al. (1981). The distance from Uwekahuna vault to the center of summit deformation may vary with 
time, because the deformation center commonly shifts in position along a broad swath, from near the center of Kilauea caldera to a site south of Halemaumau (see fig. 3 of Swanson et al., 1976b, or fig. 5 of Fiske and Kinoshita, 1969). Accordingly, we let $d=2-4 \mathrm{~km}$. Substituting these values into eq. 3 , we obtain the results shown in Table II. For $d=f=3 \mathrm{~km}$, the result is $\Delta V / \Delta \tau$ uwe $=0.32 \times 10^{6} \mathrm{~m}^{3} / \mu \mathrm{rad}$. We point out that the relationship $\Delta V / \Delta \tau_{\text {uwe }}=0.35 \times 10^{6} \mathrm{~m}^{3} / \mu \mathrm{rad}$ is implicit in fig. 13 of Eaton (1962), which is based in part on an independent measurement of ground tilt at Kilauea summit during January-April 1960.

TABLE II

$\Delta V / \Delta \tau_{\text {uwe }}\left(10^{6} \mathrm{~m}^{3} / \mu \mathrm{rad}\right)$ from equation 4

\begin{tabular}{llll}
\hline Depth $(\mathrm{km})$ & \multicolumn{3}{l}{ Distance $(\mathrm{km})$} \\
\cline { 2 - 4 } & 2.0 & 3.0 & 4.0 \\
\hline 2.0 & 0.09 & 0.21 & 0.46 \\
3.0 & 0.21 & 0.32 & 0.54 \\
4.0 & 0.46 & 0.54 & 0.75 \\
\hline
\end{tabular}

Theoretical relation between tilt changes at Uwekahuna and volume changes in Kilauea's summit magma reservoir, based on the the Mogi (1958) model.

Another approach to the problem is to empirically compare observed tilt changes at Uwekahuna with surface volume changes derived from summit leveling results, preferably for well-defined intervals of rapid deformation. Such a comparison for four large summit deflations ranging in magnitude from -17 $\mu \mathrm{rad}$ in July 1963 to -205 $\mu \mathrm{rad}$ during September 1975-January 1976 is provided in Table III. The measured ratio of volume change to summit tilt change, $\Delta V / \Delta \tau_{\text {uwe }}$, for these four cases varies from 0.23 to $0.45 \times 10^{6}$ $\mathrm{m}^{3} / \mu \mathrm{rad}$, with a mean value of $0.33 \times 10^{6} \mathrm{~m}^{3} / \mu \mathrm{rad}$. Results for smaller inflation and deflation episodes at Kilauea are less consistent (J. Dvorak, pers. commun., 1983), owing in part to larger uncertainties in measured tilt and volume changes.

A final estimate of the relation between summit storage volume and Uwekahuna tilt changes can be obtained by comparing observed tilt changes with the volume of magma extruded during early episodes of the 19691971 Mauna Ulu eruption. Table IV includes tilt and extruded volume data for the first 12 episodes of that eruption. Swanson (1972) noted that this early part of the eruption was characterized by close interplay between summit storage and rift zone extrusion and by negligible net summit deformation. In this case, the measured ratio $\Delta V / \Delta \tau$ uwe ranges from 0.19 to $0.50 \times 10^{6} \mathrm{~m}^{3} / \mu \mathrm{rad}$, with a mean value of $0.34 \times 10^{6} \mathrm{~m}^{3} / \mu \mathrm{rad}$.

Although each of these calculations suffers from its own limitations, there is remarkably good agreement between the result of Eaton (1962), 
TABLE III

$\Delta V / \Delta \tau_{\text {uwe }}\left(10^{6} \mathrm{~m}^{3} / \mu \mathrm{rad}\right)$ from measured volume and tilt changes

\begin{tabular}{rlll}
\hline Date & $\Delta V\left(10^{6} \mathrm{~m}^{3}\right)$ & $\Delta \tau_{\text {uwe }}(\mu \mathrm{rad})$ & $\begin{array}{l}\Delta V / \Delta \tau_{\text {uwe }} \\
\left(10^{6} \mathrm{~m}^{3} / \mu \mathrm{rad}\right)\end{array}$ \\
\hline $5 / 9 / 63-7 / 1 / 63$ & -7.6 & -33 & 0.23 \\
$7 / 1 / 63-10 / 5 / 63$ & -7.6 & -17 & 0.45 \\
$10 / 5 / 63-9 / 23 / 75$ & -22.9 & -75 & 0.31 \\
$9 / 23 / 75-1 / 8 / 76$ & -66.8 & -205 & 0.33 \\
& & & Average $=0.33 \pm 0.06$
\end{tabular}

Comparison of tilt changes measured at Uwekahuna Vault along a $\mathrm{N} 60^{\circ} \mathrm{W}$ azimuth and volume changes derived from repeat leveling surveys on the indicated dates. $\mathrm{N} 60^{\circ} \mathrm{W}$ is representative of the azimuth from Uwekahuna Vault to the typical deformation center observed by leveling after large summit deflations. These are minimum estimates, because we assume that benchmark HVO 23 near Bird Park, $2.5 \mathrm{~km}$ northwest of HVO, remained stable relative to a distant base during these summit deflations. Modeling by J. Dvorak (pers. commun., 1983) suggests that this may introduce an error of $10-20 \%$ in the calculated volumes.

\section{TABLE IV}

Extruded volume and summit tilt changes during the 12 eruptive episodes at Mauna Ulu during 1969

\begin{tabular}{lcll}
\hline Date (1969) & $\begin{array}{l}\text { Volume } \\
\text { erupted } \\
\left(10^{6} \mathrm{~m}^{3}\right)\end{array}$ & $\begin{array}{l}\text { Uwekahuna } \\
\text { tilt change } \\
(\mu \text { rad })\end{array}$ & $\begin{array}{l}V / \Delta \tau_{\text {uwe }} \\
\left(10^{6} \mathrm{~m}^{3} / \mu \mathrm{rad}\right)\end{array}$ \\
\hline May 24-25 & 4.5 & -23.1 & 0.19 \\
May 27-29 & 3.5 & -7.4 & 0.47 \\
June 12-13 & 4.0 & -15.1 & 0.26 \\
June 25-26 & 4.5 & -15.9 & 0.28 \\
July 15 & 4.0 & -13.7 & 0.29 \\
August 3-4 & 3.5 & -12.1 & 0.29 \\
August 5-6 & 4.0 & -12.6 & 0.32 \\
August 22 & 3.5 & -11.1 & 0.32 \\
September 6-7 & 12.0 & -29.9 & 0.40 \\
October 10-13 & 4.0 & -11.1 & 0.36 \\
October 20 & 10.5 & -21.0 & 0.50 \\
December 30 & 11.0 & -24.7 & 0.45 \\
& & Average $=$ & $0.34 \pm 0.9$
\end{tabular}

Tilt changes are from the Uwekahuna short-base water-tube tiltmeter, computed along a $\mathrm{N} 60^{\circ} \mathrm{W}$ azimuth from Uwekahuna to the average center of summit deformation. Erupted volumes are from table 5 of Swanson et al. (1979). 
the theoretical Mogi model calculation, the summit volume change vs. tilt comparison, and the Mauna Ulu extruded volume vs. summit tilt comparison (Table V). We therefore adopt for our purposes:

$\Delta V / \Delta \tau_{\text {uwe }}=0.33 \times 10^{6} \mathrm{~m}^{3} / \mu \mathrm{rad}$

We attribute observed deviations from this generalized result to:

(1) lateral shifts of the summit deformation center with respect to Uwekahuna;

(2) departures from elasticity during exceptionally large summit deflations;

(3) magma which escapes geodetic detection by moving passively through the summit reservoir or into the rift zones; and

(4) other unmodeled complexities of the Kilauea system. These include the elastic properties of rocks surrounding the summit magma reservoir, and the compressibility of Kilauea magma under reservoir conditions. Because these parameters are poorly constrained, we assume for simplicity that surface volume changes are equal to magma volume changes in the summit reservoir.

TABLE V

Four estimates of the relation between summit tilt change measured at Uwekahuna vault and volume change in Kilauea's summit magma reservoir

\begin{tabular}{lll}
\hline Source & $\begin{array}{l}\text { Range } \\
\left(10^{6} \mathrm{~m}^{3} / \mu \mathrm{rad}\right)\end{array}$ & $\begin{array}{l}\text { Average } \\
\left(10^{6} \mathrm{~m}^{3} / \mu \mathrm{rad}\right)\end{array}$ \\
\hline Eaton (1962) & - & 0.35 \\
Mogi (1958) model & $0.19-0.75$ & 0.32 \\
Summit leveling & $0.23-0.45$ & 0.33 \\
Mauna Ulu extrusion & $0.19-0.50$ & 0.34 \\
& Average $=$ & 0.33 \\
\hline
\end{tabular}

RESULTS

Magma supply during two intervals of oscillatory summit tilt

The approach outlined above is most directly applicable when: (1) the center of summit deformation does not shift laterally with respect to Uwekahuna; and (2) magma movements into the rift zone are well recorded by summit deformation. Both criteria were satisfied during periods of oscillatory summit tilting in May-December 1969 and March-August 1980.

The first interval includes episodes 1-12 of the 1969-1971 Mauna Ulu eruption from Kilauea's upper ERZ. These early episodes were characterized 
by close interplay between summit magma storage and ERZ extrusion, as periods of sustained summit inflation and weak eruption alternated with periods of rapid summit deflation and strong eruption (Swanson et al., 1979). Swanson (1972) pointed out that a negligible amount of net summit deformation occurred during this interval, and combined that fact with observed volumes of extrusion to calculate an average magma supply rate of $9 \times 10^{6} \mathrm{~m}^{3} /$ month. Application of our model to this same interval serves two purposes. First, it allows a direct comparison of our result with that of Swanson (1972), thereby providing a calibration of our indirect technique against a direct estimate. Second, it forms the basis for a comparison of supply rates to Kilauea for two similar intervals separated by 11 years, which together span the November 1975 Kalapana earthquake and July 1975 reawakening of Mauna Loa volcano.

We calculate from the Uwekahuna water-tube tilt record that the cumulative summit deflation along a $\mathrm{N} 60^{\circ} \mathrm{W}$ summit-radial vector from Uwekahuna during 24 May-31 December 1969 was $235 \mu \mathrm{rad}$. During the same interval, the net summit inflation was $5 \mu \mathrm{rad}$. From eq. 4 , we calculate that $77 \times 10^{6} \mathrm{~m}^{3}$ of magma was added to the ERZ, and that summit storage increased by $2 \times 10^{6} \mathrm{~m}^{3}$ during this 7.25 -month interval. This implies a mean supply rate of $(77+2) / 7.25=10.9 \times 10^{6} \mathrm{~m}^{3} /$ month. For the same interval, Swanson (1972) calculated a mean extrusion rate of $9.9 \times 10^{6} \mathrm{~m}^{3} /$ month, which he adjusted to $8.4 \times 10^{6} \mathrm{~m}^{3} /$ month to account for $15 \%$ vesicularity in surface flows.

The two approaches can be better reconciled by allowing for a small, unmonitored increase in rift-zone storage during this interval. If we exclude for this reason those summit deflations that were not associated in time with the 12 eruptive episodes (Table IV), the cumulative deflation is reduced to $188 \mu \mathrm{rad}$. This value implies a mean supply rate available for extrusion of $8.8 \times 10^{6} \mathrm{~m}^{3} / \mathrm{month}$, in good agreement with Swanson's (1972) corrected result.

A second interval of interest is March-August 1980, when summit deformation oscillated between steady inflation and gradual deflation with no surface extrusion. The close interaction between summit tilt and ERZ seismicity during this interval suggests that magma delivered to the summit reservoir leaked episodically into the ERZ during gradual summit subsidence events. In this respect, the period March-August 1980 was similar to MayDecember 1969 , except that in the later period magma was intruded into and stored within the ERZ rather than being erupted at Mauna Ulu.

Results of our model for March-August 1980 are illustrated graphically in Fig. 6. We interpret the Uwekahuna water-tube tilt record as an approximate measure of summit magma storage versus time. Also shown is the cumulative deflation of the summit region, interpreted as a record of increasing rift-zone storage versus time. We sum the summit and rift-zone storage records to obtain an approximate history of total magma supply, and compute the magma-supply rate as a function of time. The cumulative summit 
deflation along a summit-radial $\mathrm{N} 60^{\circ} \mathrm{W}$ vector during March-August 1980 was $105 \mu \mathrm{rad}$, resulting in a net deflation of $14 \mu \mathrm{rad}$. This implies a mean supply rate of $(34.6-4.6) / 6=5.0 \times 10^{6} \mathrm{~m}^{3} /$ month, or roughly half of the rate computed for May-December 1969.

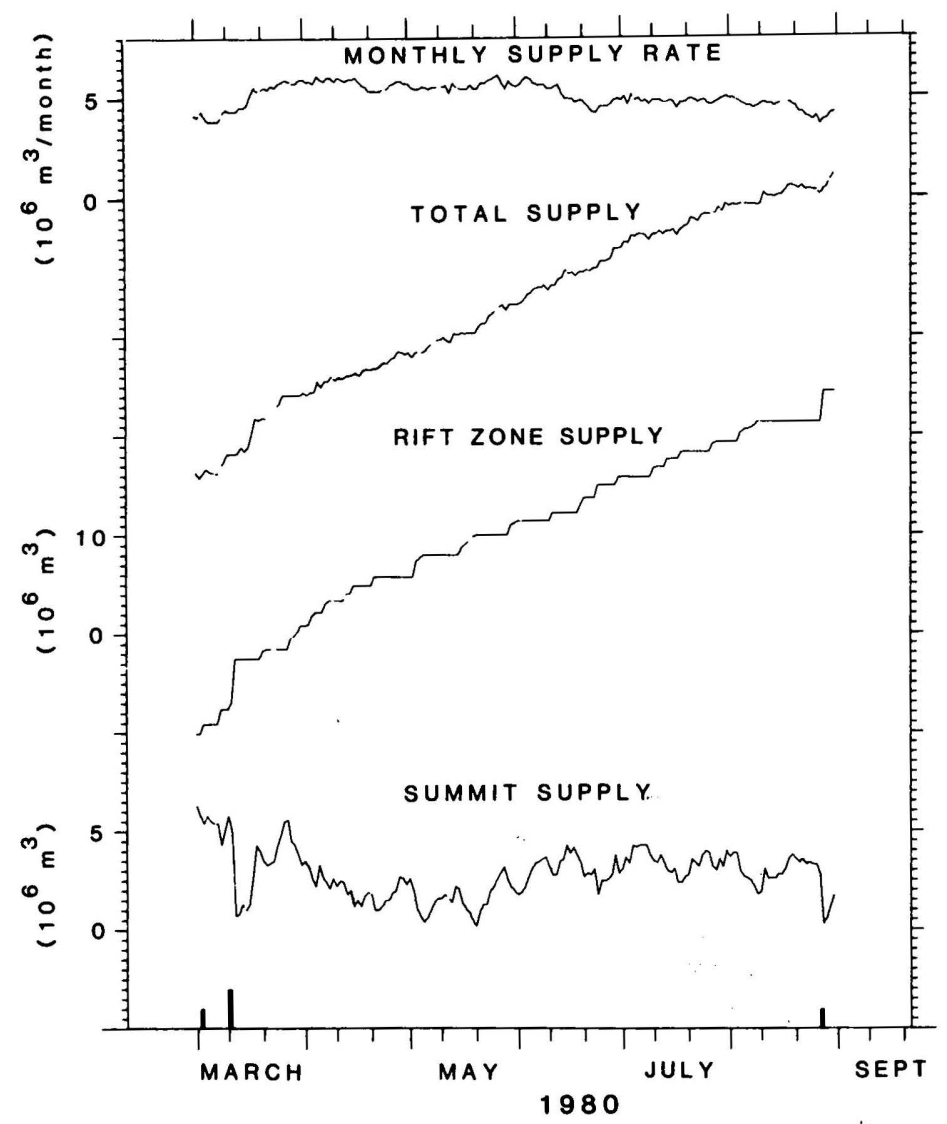

Fig. 6. Inferred magma supply to Kilauea during March-August 1980. The Uwekahuna water-tube tiltmeter record (bottom) shows a sequence of summit tilt oscillations interpreted to reflect episodic magma transfer from summit to ERZ storage. Intrusions into the ERZ on March 2 and August 27, 1980 are indicated by short bars at the bottom of the figure; a small eruption on March 10 is marked by a longer bar. An arbitrary zero was used in each case except the monthly supply rate.

We stress that the major strengths of this approach are its simplicity and applicability to the entire Uwekahuna water-tube tilt record (1956-present). Our results are admittedly subject to several assumptions and uncertainties and are not intended to supersede more detailed analyses for specific intervals by other authors (e.g., Swanson, 1972; Duffield et al., 1982; Dvorak et al., 1983). 
Encouraged by the comparison between our model for magma supply during May-December 1969 and Swanson's (1972) more direct estimate for the same interval, we now extend our calculations to the entire Uwekahuna water-tube tilt record (Fig. 7). Tilt changes were calculated on a monthly basis by differencing daily tilt values separated by 30 days. During July 1956-April 1983, our model suggests that summit storage increased by $53 \times 10^{6} \mathrm{~m}^{3}$, while roughly $2284 \times 10^{6} \mathrm{~m}^{3}$ of magma entered the ERZ and SWRZ combined. For comparison, roughly $172 \times 10^{6} \mathrm{~m}^{3}$ and $623 \times 10^{6}$ $\mathrm{m}^{3}$ of basalt were extruded from Kilauea's summit area and rift zones, respectively, during this interval. Thus, only $35 \%$ of the magma supplied to Kilauea since 1956 has been extruded to date; the rest resides in storage within the volcano's rift zones.

Our calculations suggest that the average rate of magma supply to Kilauea

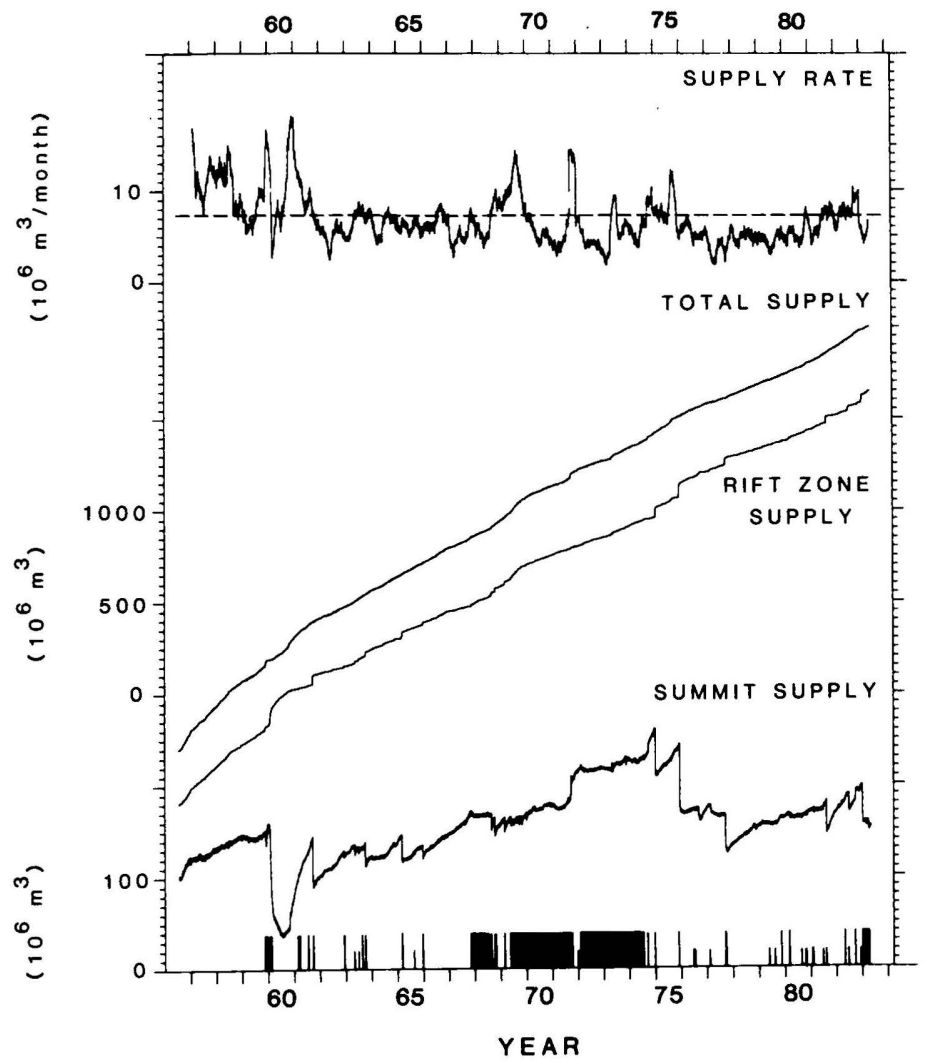

Fig. 7. Inferred magma supply to Kilauea during July 1956-April 1983. The average monthly supply rate of $7.2 \times 10^{6} \mathrm{~m}^{3} /$ month is indicated by a dashed line. Intrusions are indicated by short bars at the bottom, eruptions by longer bars. An arbitrary zero was used in each case except the monthly supply rate. 
during $1956-1983$ was $7.2 \times 10^{6} \mathrm{~m}^{3} /$ month, about $80 \%$ of the long-term rate proposed by Swanson (1972). This small discrepancy is within the uncertainty of our model, but close examination suggests that it might nevertheless be meaningful. For example, Fig. 7 suggests that magma supply to Kilauea was relatively high during 1957-1958 (11.3 $\left.\times 10^{6} \mathrm{~m}^{3} / \mathrm{month}\right)$, 1959-1961 (9.5 × 106 $\mathrm{m}^{3} /$ month $), 1968-1969\left(8.6 \times 10^{6} \mathrm{~m}^{3} /\right.$ month $)$, late $1971\left(10.3 \times 10^{6} \mathrm{~m}^{3} /\right.$ month $)$ and $1974-1975\left(7.3 \times 10^{6} \mathrm{~m}^{3} / \mathrm{month}\right)$. The first interval is anomalous in that it does not include any unusual eruptive activity at Kilauea. However, the second interval includes the large Kapoho eruption from the lower ERZ in 1960, and the next three bracket the sustained Mauna Ulu eruptions during 1969-1971 and 1972-1974.

The most sustained period of relatively low supply at Kilauea since 1956 spanned the interval 1976-1981, immediately following the 1975 Kalapana earthquake. Our calculations suggest that magma supply increased from $5.3 \times 10^{6} \mathrm{~m}^{3} /$ month during 1976 to $8.1 \times 10^{6} \mathrm{~m}^{3} /$ month during 1982 . However, this apparent change may partly reflect disruption of the volcano's shallow magma plumbing system by the Kalapana earthquake. We noted earlier that typical summit inflation/deflation cycles were largely masked by seaward movement of the volcano's south flank during 1976-1977. In addition, we know from tilt surveys along the ERZ during 1976-1980 that magma leaked passively into the rift zone without appreciably deforming the summit region, thereby violating a crucial assumption in our model.

The average rate of magma supply during 1976-1982 from our model was $5.6 \times 10^{6} \mathrm{~m}^{3} /$ month, or $1.6 \times 10^{6} \mathrm{~m}^{3} /$ month below the long-term average of $7.2 \times 10^{6} \mathrm{~m}^{3} /$ month. This implies a ,,missing" volume of $\left(1.6 \times 10^{6} \mathrm{~m}^{3} /\right.$ month) $\times\left(84\right.$ months) $\tilde{\mathrm{n}} 134 \times 10^{6} \mathrm{~m}^{3}$. However, the surface of the upper ERZ dilated by roughly $1.7 \mathrm{~m}$ during $1975-1982$, and tilt surveys show that roughly $30 \mathrm{~km}$ of the upper and middle ERZ were progressively uplifted during that interval. If dilation extended over a horizontal dimension of $30 \mathrm{~km}$ and a vertical dimension of $2 \mathrm{~km}$, the resulting volume increase could accommodate (1.7 $\mathrm{m}) \times\left(30 \times 10^{3} \mathrm{~m}\right) \times\left(2 \times 10^{3} \mathrm{~m}\right)=102 \times 10^{6} \mathrm{~m}^{3}$ of magma. Tilting the same segment of rift zone by $50 \mu \mathrm{rad}$ throughout a zone $5 \mathrm{~km}$ wide implies an additional volume increase of about $9 \times 10^{6} \mathrm{~m}^{3}$, for a total of $111 \times 10^{6} \mathrm{~m}^{3}$. If most of that volume leaked from the summit reservoir without associated summit deflation, our model may have significantly underestimated a near-normal supply during this interval. In any event, the steady increase in apparent supply to Kilauea during 1976-1981 implies that the volcano's relative quiescence during that interval may now have ended, as evidenced by 2 summit eruptions during 1982 and by a sustained ERZ eruption beginning in January 1983.

In summary, Swanson's (1972) long-term supply estimate of $9 \times 10^{6}$ $\mathrm{m}^{3} /$ month is probably an upper limit, because it may have been biased by above-average supply during sustained eruptions in 1968-1969 and 1971 . On the other hand, our estimate of $7.2 \times 10^{6} \mathrm{~m}^{3} / \mathrm{month}$ is a lower bound, for reasons stated earlier. This relatively good agreement between upper and lower limits for Kilauea magma supply reinforces the contention that 
Kilauea is currently among the most active volcanoes in the world, with a sustained magma supply of about $0.1 \mathrm{~km}^{3} /$ year.

\section{Partitioning between storage reservoirs}

By incorporating the chronology of eruptions and intrusions at Kilauea (Table I) into our model of magma supply (Fig. 7), we can derive an approximate history of supply to each of the volcano's principal magma reservoirs. We assume that magma is lost from Kilauea's summit reservoir through two conceptualized valves: one leading to the ERZ and the other to the SWRZ (Fig. 8). Both valves normally remain closed during periods of summit uplift; when one of the rift-zone valves opens, magma leaks from the summit reservoir and the summit subsides. We assume that the potentially open valve at any given time is determined by the location of the most recent rift-

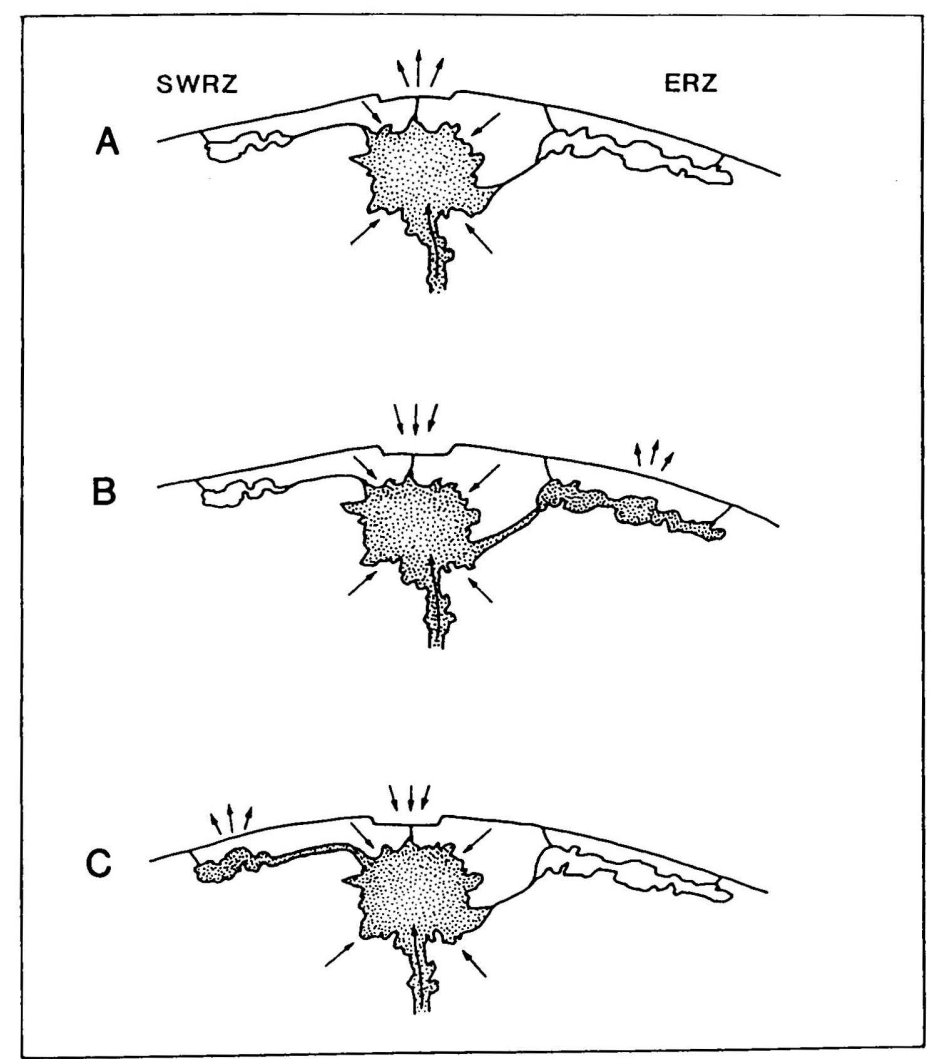

Fig. 8. Schematic diagram (not to scale) of subsurface magma transport and storage systems at Kilauea Volcano. Magma (stippled) from a zone of partial melting in the upper mantle is delivered continuously to a shallow storage reservoir beneath the volcano's summit, causing it to inflate (A). Rupture of this reservoir causes deflation and sometimes triggers summit eruptions, but since 1955 most summit magma has been delivered to the ERZ (B) or SWRZ (C). 
zone eruption or intrusion. In other words, small summit deflations continue to deliver magma to the most recently active rift zone until the routing is switched by a documented eruption or intrusion into the competing rift zone.

We conclude from the analysis illustrated in Fig. 9 that the primary role of the summit magma reservoir since 1956 has been to provide temporary storage for magma delivered from depth until it was erupted or intruded into one of the volcano's rift zones. Our calculations indicate that a negligible amount of the magma supplied to Kilauea since 1956 currently resides beneath the summit region; roughly $35 \%$ has been extruded and $65 \%$ resides in rift-zone storage.

A second implication of Fig. 9 is that the ERZ has been the dominant repository for summit magma since 1956, and that a large volume of potentially eruptible magma currently resides in shallow storage within the ERZ.

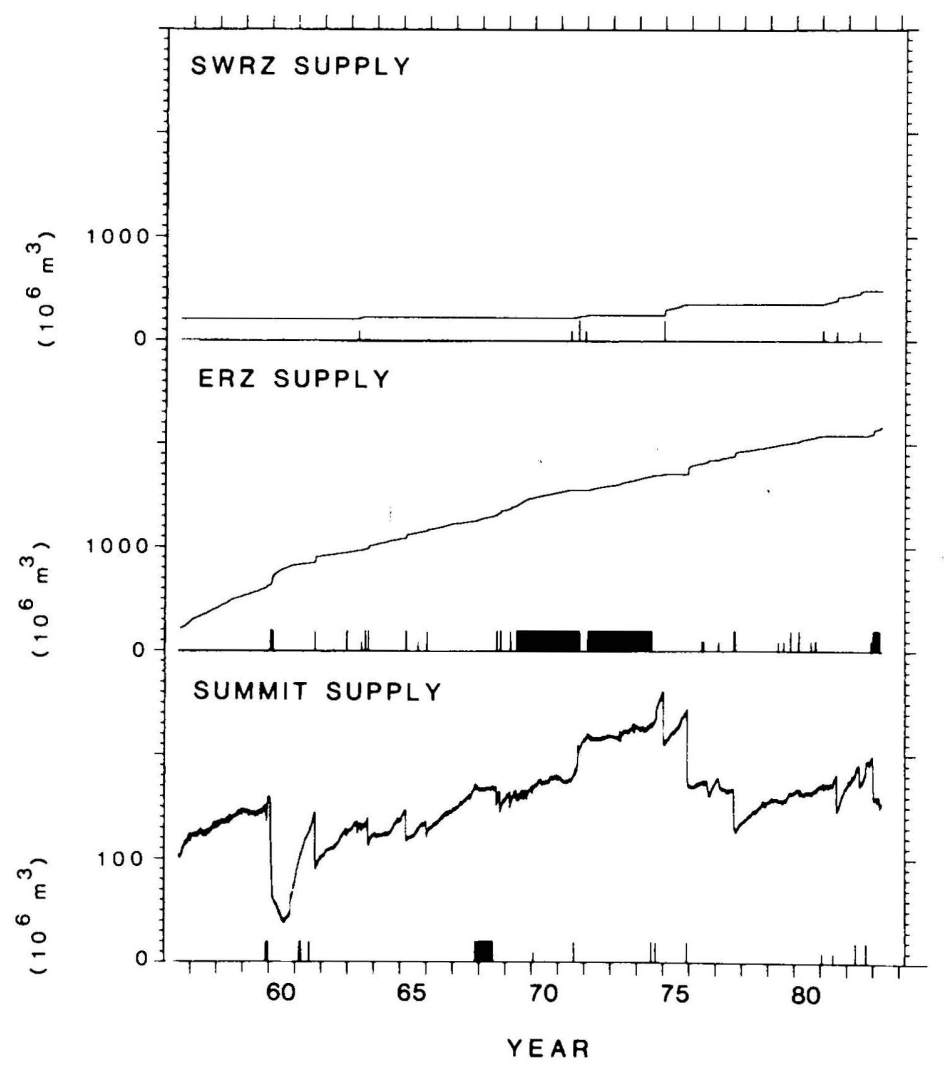

Fig. 9. History of shallow magma storage at Kilauea during 1956-1983. The Uwekahuna water-tube tilt record (bottom) provides a measure of summit magma storage versus time, with large short-term changes related to eruptions but little net change since 1956 . For each region, intrusions are indicated by short bars and eruptions by longer bars. Magma supply is referred to an arbitrary zero in each case. 
Our results indicate that roughly 55\% of Kilauea's magma supply since 1956 now resides within the ERZ, while only $10 \%$ is stored in the SWRZ. We estimate that at least $1960 \times 10^{6} \mathrm{~m}^{3}$ of basalt have been stored within the ERZ since 1956, 30\% of which has accumulated there since the 1975 Kalapana earthquake. Should a vent along Kilauea's middle or lower ERZ tap this magma reservoir in the foreseeable future, the potential exists for an event comparable to the largest eruptions in Kilauea's recorded history. Indeed, the sustained eruption from Kilauea's middle ERZ which began in January 1983 and continues at the time of this writing (December 1983) appears to fit this scenario.

Finally, Fig. 9 further illustrates the effect on Kilauea's shallow magma plumbing system of the 1975 Kalapana earthquake. For 5 years following the earthquake, virtually all of the magma supplied to Kilauea was quickly routed to the ERZ to accommodate continuing dilation of the rift zone. This process was largely complete by 1981 , when intrusive activity shifted to the SWRZ. The SWRZ (which also dilated during the Kalapana earthquake) was replenished by 1982 , a year which included the first Kilauea summit eruption since the earthquake and the return of Kilauea's magma supply rate to its long-term average (Fig. 7). The sustained 1983 eruption may therefore mark the completion of Kilauea's recovery from the Kalapana earthquake and herald a return to more frequent activity exemplified by the interval 1956-1975.

\section{DISCUSSION}

\section{Causes of variable magma supply}

Apparent fluctuations in the rate of shallow magma supply to Kilauea might be attributable to one or more of the following causes:

(1) changes in the deep plumbing or storage system that delivers magma from the mantle to shallow crustal depths;

(2) changes in the volcano's geodetic response to shallow magma supply;

(3) a physical connection between the deep plumbing systems at Kilauea and neighboring Mauna Loa; or

(4) changes in the rate of magma supply from depth.

One factor that might plausibly influence the rate of shallow magma accumulation beneath Kilauea is the existence of a relatively deep storage reservoir between the volcano's source region and its summit reservoir. For example, an increase in deep storage caused by disruption of Kilauea's plumbing system during the 1975 Kalapana earthquake might account for apparently below-average supply for several years following the quake. Mogi $(1958$, p. 117) first proposed such a reservoir at 20-30 km depth based on far-field leveling results, but this interpretation was later called into question by Eaton (1962). Ellsworth and Koyanagi (1977) modeled the three-dimensional seismic structure beneath Hawaii and concluded that 
large-volume concentrations of magma are absent from the lower crust and upper mantle to depths of at least $40 \mathrm{~km}$. Neither seismic nor grounddeformation data are of sufficient resolution to unambiguously refute the existence of a modest size storage reservoir in the upper mantle beneath Kilauea. On the other hand, there exists no clear evidence for such a structure; we therefore do not call upon deep storage changes to explain fluctuations in shallow magma supply.

A second reasonable interpretation of apparent changes in supply to Kilauea involves changes in the volcano's geodetic response to magma influx from depth. Specifically, the 1975 Kalapana earthquake may have caused pervasive but temporary leaks in Kilauea's shallow plumbing system, so that proportionally more magma escaped geophysical detection during 1976-1981. The earthquake clearly had a profound effect on shallow magma storage at Kilauea, as evidenced by the resulting large summit deflation and by frequent post-earthquake intrusions.

The near-coincidence of the July 1975 reawakening of Mauna Loa and the November 1975 Kalapana earthquake at Kilauea makes it difficult to separate earthquake effects from a possible influence on Kilauea's magma supply by its giant neighbor to the north. Several writers have noted an apparent inverse relationship between eruptive activity at these volcanoes (e.g., Moore, 1970; Klein, 1982), and there is seismic evidence that they are fed from a common source region in the upper mantle (Ellsworth and Koyanagi, 1977). A strong argument against a common source can be made on petrologic grounds (Wright et al., 1979), but this does not preclude some physical connection between the eruptive state of one volcano and the rate of magma supply to the other. For example, stresses induced by inflation of Mauna Loa might inhibit magma supply to Kilauea, or vice versa. The potential for such an interaction between Kilauea and Mauna Loa is implied by the persistence of strike-slip earthquakes in the Kaoiki region along the boundary between the volcanoes (Endo et al., 1978).

In our opinion, little evidence exists that Mauna Loa has interfered with Kilauea's magma supply in any appreciable way since 1975 . Kilauea's supply rate fluctuated significantly during Mauna Loa's 1951-1974 repose, and it remained constant or increased during 1976-1981, while Mauna Loa continued to inflate following its 1975 summit eruption. We therefore suggest that simultaneous inflation of Mauna Loa and increasing magma supply to Kilauea since 1976 may be separate manifestations of a common cause: an episode of relatively rapid magma supply from depth.

The rate at which magma is delivered to Kilauea's shallow storage reservoirs might be a direct reflection of the rate of magma supply from the upper mantle. The best available monitor of magma production beneath Hawaii's volcanoes is the time-averaged seismic-energy output of sporadic harmonic tremor which originates in Kilauea's inferred source region at $40-50 \mathrm{~km}$ depth. We have therefore plotted (Fig. 10): (1) the product of reduced displacement and duration as an index of energy release from deep 
tremor (from Aki and Koyanagi, 1981); and (2) total shallow magma supply (summit + ERZ + SWRZ from our model), each as a function of time during 1962-1982. Because we are interested in relatively subtle changes through time, we have removed linear trends of $0.275 \times 10^{6} \mathrm{~cm}^{2} \mathrm{~s} / \mathrm{year}$ and $7.4 \times 10^{6}$ $\mathrm{m}^{3} /$ year from the cumulative deep tremor and magma supply records, respectively; residuals are shown in Fig. 10.

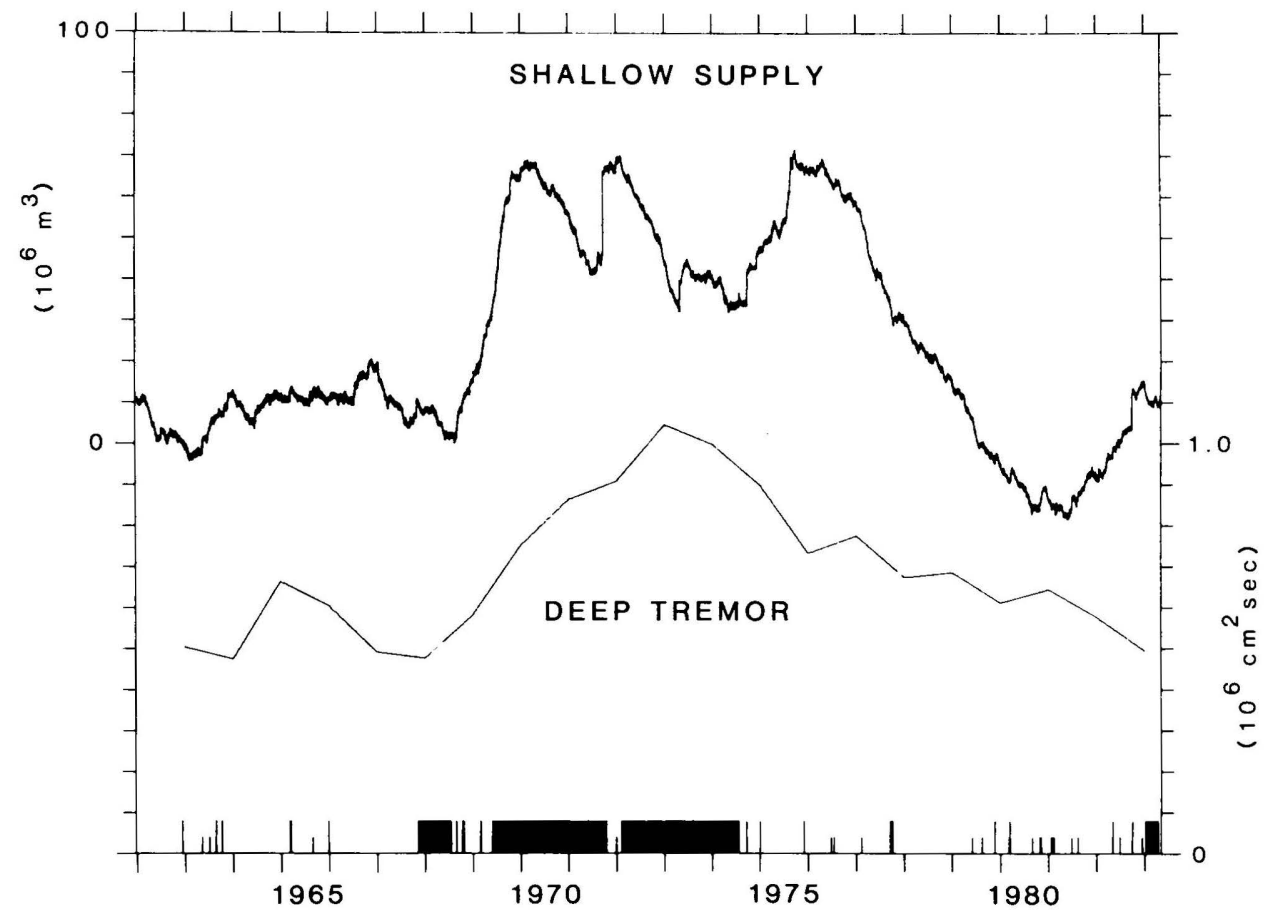

Fig. 10 Relation between shallow magma supply, deep harmonic tremor, and eruptions/ intrusions (bottom) at Kilauea during 1962-1982. To emphasize relatively subtle changes, linear trends have been removed from the cumulative magma supply and deep tremor records, and the departures from those average rates have been plotted with respect to an arbitrary zero. The interval 1969-1975 was marked by above-average magma supply, greater occurrence of deep tremor, and sustained eruptive activity at Mauna Ulu.

As noted earlier, our model suggests that the rate of shallow magma supply to Kilauea was above average during 1968-1969, 1971, and 19741975; these peaks are apparent in Fig. 10. That plot also shows a broad peak in seismic energy release from deep tremor during 1968-1975, suggesting that the rates of deep magma production and shallow supply to Kilauea may be closely linked. It is interesting to speculate that a pulse of relatively rapid magma supply during 1968-1975 may have been responsible for the sustained eruptions at Mauna Ulu during 1969-1971 and 1972-1974.

If so, this period of relatively rapid supply may also have been responsible (indirectly) for the large Kalapana earthquake in 1975. Swanson et al. 
(1976a) have argued that such movements are caused by forceful injection of magma into the ERZ, usually during frequent eruptions, generating stresses in the adjacent south flank. Viewed in this perspective, the 1975 Kalapana earthquake may have been the end result of a process that began in 1955 with the renewal of frequent ERZ activity and that culminated in the Mauna Ulu eruptions, in turn fed by a pulse of increased magma supply from depth.

It remains unclear whether pulses of magma generation at depth are responsible for periods of relatively rapid shallow supply, or if instead relatively rapid magma withdrawal from the summit reservoir effectively unloads a plumbing system in hydraulic connection to the source region, thereby triggering more rapid ascent from depth. The latter mechanism may explain relatively rapid re-inflation of Kilauea's summit magma reservoir immediately following most large deflations (e.g., 1960 Kapoho eruption). In either case, Kilauea's sustained 1983 eruption and Mauna Loa's continuing inflation (Decker et al., 1983) suggest that an episode of increased magma supply is now in progress, or will likely begin soon.

\section{ACKNOWLEDGMENTS}

Our ideas were sharpened by numerous discussions with staff of the Hawaiian Volcano Observatory during 1977-83. The manuscript benefitted from thorough reviews by R.W. Decker, D.A. Swanson, R.I. Tilling, and M. Garcia; J. Griggs and B. Myers helped with the illustrations. Research supported by the U.S. Geological Survey's Volcano Hazards Reduction Program. Special thanks to R.P. Sharp, who taught me how.

\section{REFERENCES}

Aki, K. and Koyanagi, R.Y., 1981. Deep volcanic tremor and magma ascent mechanism under Kilauea, Hawaii. J. Geophys. Res., 86: 7095-7109.

Bargar, K.E., and Jackson, E.D., 1974. Calculated volumes of individual shield volcanoes along the Hawaiian-Emperor chain, J. Res. U.S. Geol. Surv., 2: 545-550.

Björnsson, A. and Sigurdsson, O., 1978. Hraungos úr borholu í Bjarnarflagi (Volcanic eruption from a drill hole in Bjarnarflag). Náttúrufraedingurinn, 48: 19-23 (in Icelandic with English abstract).

Decker, R.W., Koyanagi, R.Y., Dvorak, J.J., Lockwood, J.P., Okamura, A.T., Yamashita, K.M. and Tanigawa, W.R., 1983. Seismicity and surface deformation of Mauna Loa Volcano, Hawaii. EOS, Trans. Am. Geophys. Union, 64(37): 545-547.

Duffield, W.A., Christiansen, R.L., Koyanagi, R.Y. and Peterson, D.W., 1982. Storage, migration, and eruption of magma at Kilauea Volcano, Hawaii, 1971-1972. J. Volcanol. Geotherm. Res., 13: 273-307.

Dvorak, J., Okamura, A. and Dieterich, J.H., 1983. Analysis of surface deformation data, Kilauea Volcano, Hawaii: October 1966 to September 1970. J. Geophys. Res., 88: 9295-9304.

Dzurisin, D. and Koyanagi, R.Y., 1981. Changed magma budget since 1975 at Kilauea Volcano, Hawaii. U.S. Geol. Surv., Open-File Rep. 81-571, 46 pp. 
Dzurisin, D., Anderson, L.A., Eaton, G.P., Koyanagi, R.Y., Lipman, P.W., Lockwood, J.P., Okamura, R.T., Puniwai, G.S., Sako, M.K. and Yamashita, K.M., 1980. Geophysical observations of Kilauea Volcano, Hawaii, 2. Constraints on the magma supply during November 1975-September 1977. J. Volcanol. Geotherm. Res., 7: 241269.

Eaton, J.P., 1962. Crustal structure and volcanism in Hawaii. Am. Geophys. Union, Geophys. Monogr., 6: 13-29.

Eaton, J.P. and Murata, K.J., 1960. How volcanoes grow. Science, 132: 925-938.

Ellis, W., 1963 (reprint of the London 1827 and Hawaii 1917 editions). Journal of William Ellis. Advertiser Publishing Company, Honolulu, Hawaii, 342 pp.

Ellsworth, W.L. and Koyanagi, R.Y., 1977. Three-dimensional crust and mantle structure of Kilauea Volcano, Hawaii. J. Geophys. Res., 82: 5379-5394.

Endo, E.T., Koyanagi, R.Y. and Klein, F.W., 1978. Geologic and seismic evidence for strike-slip faulting between Kilauea and Mauna Loa volcanoes (abstract). Hawaii Symposium on Intraplate Volcanism and Submarine Volcanism, Hilo, July 1979, p. 160.

Fiske, R.S. and Kinoshita, W.T., 1969. Inflation of Kilauea Volcano prior to its 19671968 eruption. Science, 165: 341-349.

Jackson, D.B., Swanson, D.A., Koyanagi, R.Y. and Wright, T.L., 1975. The August and October 1968 east rift eruptions of Kilauea Volcano, Hawaii. U.S. Geol. Surv., Prof. Pap. 890, 33 pp.

Jaggar, T.A. and Finch, R.H., 1924. The explosive eruption of Kilauea in Hawaii, 1924. Am. J. Sci., Ser. 5, 8: 353-374.

Keller, G.V., Skokan, C.K., Skokan, J.J., Daniels, J., Kauahikaua, J. P., Klein, D.P. and Zablocki, C.J., 1977. Geoelectric studies on the east rift, Kilauea Volcano, Hawaii Island. Hawaii Institute of Geophysics, University of Hawaii Technical Report HIG77-15.

Kinoshita, W.T., Koyanagi, R.Y., Wright, T.L. and Fiske, R.S., 1969. Kilauea Volcano The 1967-68 summit eruption. Science, 166: 459-468.

Klein, F.W., 1982. Patterns of historical eruptions at Hawaiian volcanoes. J. Volcanol. Geotherm. Res., 12: 1-35.

Koyanagi, R.Y., Unger, J.D., Endo, E.T. and Okamura, A.T., 1974. Shallow earthquakes associated with inflation episodes at the summit of Kilauea Volcano, Hawaii. In: O. Gonzales-Ferran (Editor), Proc. Symp. Andean and Antarctic Volcanology Problems, Santiago, Chile, September 1974. International Association of Volcanology and Chemistry of the Earth's Interior, Special Series.

Koyanagi, R.Y., Stevenson, P., Endo, E.T. and Okamura, A.T., 1978a. Hawaiian Volcano Observatory Summary 74, January to December 1974. U.S. Geol. Surv., Menlo Park, Calif., 164 pp.

Koyanagi, R.Y., Meagher, K., Klein, F.W. and Okamura, A.T., 1978b. Hawaiian Volcano Observatory Summary 75, January to December 1975. U.S. Geol. Surv., Menlo Park, Calif., 117 pp.

Koyanagi, R.Y., Nakata, J.S. and Tanigawa, W.R., 1981. Seismicity of the lower east rift zone of Kilauea Volcano, Hawaii. U.S. Geol. Surv., Open-File Rep. 81-984, 26 pp.

Larsen, G., Gronvold, K. and Thorarinsson, S., 1978. Volcanic eruption through a geothermal borehole at Namafjall, Iceland. Nordic Volcanological Institute, Report 78-12, Science Institute 78-10,18 pp.

Lipman, P.W., Lockwood, J.P., Okamura, R.T., Swanson, D.A. and Yamashita, K.M., 1984. Ground deformation associated with the 1975 magnitude 7.2 earthquake and resulting changes in activity of Kilauea Volcano 1975-1977. U.S. Geol. Surv., Prof. Pap., 1336, in press.

Lockwood, J.P., Koyanagi, R.Y., Tilling, R.I., Holcomb, R.T. and Peterson, D.W., 1976. Mauna Loa threatening. Geotimes, June 1976: 12-15.

Macdonald, G.A., 1959. The activity of Hawaiian volcanoes during the years 19511956. Bull. Volcanol., Ser. 2, 22: 3-70. 
Macdonald, G.A. and Abbott, A.T., 1970. Volcanoes in the Sea, The Geology of Hawaii. The University Press of Hawaii, Honolulu, Hawaii, 441 pp.

Macdonald, G.A. and Eaton, J.P., 1964. Hawaiian volcanoes during 1955, U.S. Geol. Surv., Bull. 1171, 170 pp.

Mogi, K., 1958. Relation between the eruptions of various volcanoes and the deformation of the ground surfaces around them. Tokyo Univ. Earthquake Research Inst. Bull., 36: 99-134.

Moore, J.G., 1970. Relationship between subsidence and volcano load, Hawaii. Bull. Volcanol., 34: 562-576.

Moore, J.G. and Krivoy, H.L., 1964. The 1962 flank eruption of Kilauea Volcano and structure of the east rift zone. J. Geophys. Res., 69: 2033-2045.

Moore, R.B., 1983. Distribution of differentiated tholeiitic basalts on the lower east rift zone of Kilauea Volcano, Hawaii: A possible guide to geothermal exploration. Geology, 11: 136-140.

Moore, R.B., Helz, R.T., Dzurisin, D., Eaton, G.P., Koyanagi, R.Y., Lipman, P.W., Lockwood, J.P. and Puniwai, G.S., 1980. The 1977 eruption of Kilauea Volcano, Hawaii. J. Volcanol. Geotherm. Res., $7: 189-210$.

Ryan, M.P., Koyanagi, R.Y. and Fiske, R.S., 1981. Modeling the three-dimensional structure of macroscopic magma transport systems: Application to Kilauea Volcano, Hawaii. J. Geophys. Res., 86: 7111-7129.

Richter, D.H., Ault, W.U., Eaton, J.P. and Moore, J.G., 1964. The 1961 eruption of Kilauea Volcano, Hawaii. U.S. Geol. Surv., Prof. Pap. 474-D, 34 pp.

Richter, D.H., Eaton, J.P., Murata, K.J., Ault, W.U. and Krivoy, H.L., 1970. Chronological narrative of the 1959-60 eruption of Kilauea Volcano, Hawaii. U.S. Geol. Surv., Prof. Pap. 537-E, 73-pp.

Swanson, D.A., 1972: Magma supply rate of Kilauea Volcano, 1952-1971. Science, 175: $169-170$.

Swanson, D.A., Duffield, W.A. and Fiske, R.S., 1976a. Displacement of the south flank of Kilauea Volcano: The result of forceful intrusions of magma into the rift zones. U.S. Geol. Surv., Prof. Pap. 963, 39 pp.

Swanson, D.A., Jackson, D.B., Koyanagi, R.Y. and Wright, T.L., 1976b. The February 1969 east rift eruption of Kilauea Volcano, Hawaii. U.S. Geol. Surv., Prof. Pap. 891, $30 \mathrm{pp}$.

Swanson, D.A., Duffield, W.A., Jackson, D.B. and Peterson, D.W., 1979. Chronological narrative of the 1969-71 Mauna Ulu eruption of Kilauea Volcano, Hawaii. U.S. Geol. Surv. Prof. Pap. 1056, 55 pp.

Tilling, R.I., Koyanagi, R.Y., Lipman, P.W., Lockwood, J.P., Moore, J.G. and Swanson, D.A., 1976. Earthquakes and related catastrophic events, Island of Hawaii, November 29, 1975: A preliminary report. U.S. Geol. Surv., Circ. 740, 33 pp.

Wright, T.L. and Fiske, R.S., 1971. Origin of differentiated and hybrid lavas of Kilauea Volcano, Hawaii. J. Petrol., 12: 1-65.

Wright, T.L., Kinoshita, W.T. and Peck, D.L., 1968. March 1965 eruption of Kilauea Volcano and the formation of Makaopuhi lava lake. J. Geophys. Res., 73: 31813205.

Wright, T.L., Shaw, H.R., Tilling, R.I. and Fiske, R.S., 1979. Origin of Hawaiian tholeiitic basalt: a quantitative model (abstract). IAVCEI Hawaii Symposium on Intraplate Volcanism and Submarine Volcanism, Hilo, Hawaii, July 16-22, 1979. 